\title{
36. MAGNETIC PETROLOGY AND MAGNETIC PROPERTIES OF WESTERN PACIFIC GUYOTS: IMPLICATIONS FOR SEAMOUNT PALEOPOLES ${ }^{1}$
}

\author{
Jeff Gee ${ }^{2}$ and Masao Nakanishi ${ }^{3}$
}

\begin{abstract}
Despite the importance of seamount paleopoles in reconstructing past tectonic motions of the Pacific Plate, few data exist on the magnetic properties and processes of remanence acquisition in seamounts. We present a basic magnetic characterization and a detailed petrographic and microprobe study of the oxide minerals in mildly to strongly alkalic lavas recovered from five western Pacific guyots sampled during Ocean Drilling Program Leg 144. The Ti-rich chrome spinel compositions and Al-and Mg-enrichment in titanomagnetites reflect the alkalic nature of the lavas. The alteration history of these samples is diverse, ranging from low-temperature oxidation to highly oxidizing conditions resulting in an assemblage of magnesioferrite + titanohematite. The natural remanent magnetization (NRM) intensities for all five guyots are quite similar, yielding a combined arithmetic mean NRM intensity of $3.53 \mathrm{~A} / \mathrm{m}$, similar to previously reported values from dredged and drilled seamount material. The mean Königsberger ratio (9.8) implies an approximate 10\% contribution of induced magnetization. Systematic discrepancies between the observed inclinations and inclinations derived from the magnetic anomaly data for Lo-En, MIT, and Takuyo-Daisan guyots are compatible with a significant bias from viscous and induced magnetization in these Cretaceous guyots.
\end{abstract}

\section{INTRODUCTION}

Paleopoles derived from seamount magnetic anomalies constitute a major source of data for reconstructing the past motions of the Pacific Plate (e.g., Francheteau et al., 1970). Despite the importance of seamount paleopoles, data on the magnetic properties of seamount rocks necessary to constrain model solutions are relatively scarce. Significant drill-core penetration into seamounts/guyots, as accomplished during Ocean Drilling Program (ODP) Leg 144, provides the most direct method of assessing the validity of paleopoles derived from seamount magnetic anomalies. Studies of material dredged from seamounts (Merrill and Burns, 1972; Furuta et al., 1980; Gee et al., 1988) and samples from uplifted, subaerially exposed seamounts (Gee et al., 1989), however, provide valuable complementary information on the magnetic properties of seamount rocks. For example, such studies can constrain the potential contribution of intrusive rocks likely to constitute a significant portion of the volcanic edifice but not easily sampled by drilling. Combined data from these various approaches provide the best opportunity to understand the processes of remanence acquisition in seamounts and to assess the potential errors in seamount paleopole data.

Characterization of the magnetic mineralogy and alteration history of seamount rocks may further aid in evaluating the significance of the remanent magnetization. For example, the high ulvöspinel contents (and inferred low original Curie temperatures) of titanomagnetites in hotspot-related volcanic rocks from the Ninetyeast Ridge have been interpreted as circumstantial evidence for a delayed acquisition of a chemical remanence acquired as Curie temperatures were elevated during oxidation (Smith et al., 1991). Rice et al. (1980) have documented remagnetization of rocks from the Bermuda Seamount related to hydrothermal alteration associated with intrusive activity that substantially postdates seamount construction. Similarly, welldefined anomalous remanence directions from the La Palma Seamount Series have been attributed to hydrothermal alteration in an

\footnotetext{
${ }^{1}$ Haggerty, J.A., Premoli Silva, I., Rack, F., and McNutt, M.K. (Eds.), 1995. Proc. $O D P$, Sci. Results, 144: College Station, TX (Ocean Drilling Program)

${ }^{2}$ Lamont-Doherty Earth Observatory, Palisades, New York 10964, U.S.A. (Present address: Scripps Institution of Oceanography, University of California, San Diego, La Jolla, CA 92093-0215, U.S.A.)

${ }^{3}$ Ocean Research Institute, 1-15-1 Minamidai, Nakano-ku, Tokyo 164.Japan. (Present address: Scripps Institution of Oceanography, University of California, San Diego, La Jolla, CA 92093-0215, U.S.A.)
}

interval of opposite polarity to that of the original thermal remanence (Gee et al., 1993). In this paper, we present a petrographic and microprobe characterization of the oxide mineralogy and alteration in lavas from western Pacific guyots. We also report basic magnetic properties (i.e., natural remanence, susceptibility, magnetic stability, and Curie temperature) for these samples and briefly discuss the relevance of these mineralogical and magnetic data to seamount magnetization and the determination of seamount paleopoles. A more complete characterization of the magnetic properties is in progress, and a more detailed comparison of the magnetic data and available anomaly modeling results will accompany this work.

Drilling during Leg 144 sampled volcanic basement at five guyots in the western Pacific (see site map preceding title page), with minimum biostratigraphic ages ranging from the Paleocene to the Early Cretaceous (Premoli Silva, Haggerty, Rack, et al., 1993). Rock names used here are based on shipboard petrographic descriptions and X-rayfluorescence whole-rock geochemical data, supplemented by shorebased geochemical analyses and mineral chemistry data from selected flow units (Christie et al., this volume). For a more detailed description of the petrography and geochemistry of lavas recovered during Leg 144, the reader is referred to papers by Christie et al. and Dieu (both in this volume).

Samples recovered from Site 871 on Limalok Guyot $\left(5^{\circ} 23.4^{\prime} \mathrm{N}\right.$, $172^{\circ} 20.6^{\prime} \mathrm{E}$; Paleocene) are strongly silica-undersaturated basanites and basanitoids, with magnesium numbers $\left(\mathrm{Mg} \#=100 \cdot \mathrm{Mg}^{2+} /\left[\mathrm{Fe}^{2+}+\right.\right.$ $\left.\mathrm{Mg}^{2+}\right]$ ) of 65 to 72 . Differentiated alkalic basaltic lavas and hawaiites were recovered from Lo-En Guyot (Site $872 ; 10^{\circ} 5.8^{\prime} \mathrm{N}, 162^{\circ} 52.0^{\prime} \mathrm{E}$ ), The oldest sediments recovered on Lo-En Guyot are Santonian in age (Premoli Silva, Haggerty, Rack, et al., 1993) and a radiometric age of $112.8 \pm 1.2 \mathrm{Ma}$ has been reported for the volcanic basement (Pringle and Duncan, this volume). Five sites (873-877) were located on Wodejebato Guyot $\left(11^{\circ} 53.8^{\prime} \mathrm{N}, 164^{\circ} 55.2^{\prime} \mathrm{E}\right)$, with basement recovery ranging from $\sim 57 \mathrm{~m}$ at Hole $873 \mathrm{~A}$ to $<1 \mathrm{~m}$ at Hole $877 \mathrm{~A}$. Radiometric age determinations for Wodejebato Guyot range from 79 to $85 \mathrm{Ma}$ (weighted mean $83.2 \pm 1.1 \mathrm{Ma}$; Pringle and Duncan, this volume); however, reworked Cenomanian nannofossils in Campanian clays overlying volcanic basement (Nakanishi et al., 1992) provide evidence for an earlier volcanic episode as well. Petrographically, all samples from Wodejebato Guyot are alkalic basalts that are interpreted as only slightly silica undersaturated; however, none of the material recovered proved suitable for bulk-rock geochemical analysis. The deepest basement penetration $(\sim 200 \mathrm{~m})$ was at MIT Guyot $\left(27^{\circ} 19.1^{\prime} \mathrm{N}\right.$, 
$151^{\circ} 53.0^{\prime} \mathrm{E}$ ), where 35 flow units were recognized. Samples from MIT Guyot include basanitoids, differentiated alkali olivine basalts, and hawaiites, with $\mathrm{Mg}$ numbers as low as $36 .{ }^{40} \mathrm{Ar} /{ }^{39} \mathrm{Ar}$ incremental heating studies indicate an age of $119.6 \pm 0.7 \mathrm{Ma}$ for the upper hawaiitic flows and $121.9 \pm 0.9 \mathrm{Ma}$ for the lower alkalic lavas from MIT Guyot (Pringle and Duncan, this volume). No whole-rock geochemical data are available for the single lava unit recovered from Takuyo-Daisan Guyot (Site $879 ; 34^{\circ} 10.5^{\prime} \mathrm{N}, 144^{\circ} 18.6^{\prime} \mathrm{E}$ ); however the composition of clinopyroxenes suggests that this unit represents a transitional basalt (Christie et al., this volume). Ozima et al. (1983) have reported an ${ }^{40} \mathrm{Ar} /{ }^{39} \mathrm{Ar}$ age of $102 \mathrm{Ma}$ (no error limits) for Takuyo-Daisan Guyot; however, Pringle and Duncan (this volume) report an age of $118.4 \pm$ 1.8 Ma for this guyot.

\section{METHODS}

Approximately 60 polished thin sections were examined in reflected light, typically at a magnification of $600 \times$ in oil, to assess the mineralogy of the iron-titanium oxide minerals and provide a qualitative estimate of the type and degree of alteration. Quantitative analysis of mineral compositions was obtained by electron microprobe analysis using a 4-channel CAMECA electron microprobe at Lamont-Doherty Earth Observatory (LDEO). All analyses were made using an accelerating voltage of $15 \mathrm{kV}$ and a specimen current of $20 \mathrm{nA}$, either with a focused beam $(\sim 3 \mu \mathrm{m}$ spot size) or in raster mode for grains with oxyexsolved ilmenite lamellae. Natural minerals were used for the standardization: hematite $(\mathrm{Fe})$, rutile $(\mathrm{Ti})$, enstatite $(\mathrm{Mg}, \mathrm{Si})$, anorthite ( $\mathrm{Al}, \mathrm{Ca})$, uvarovite $(\mathrm{Cr})$, and rhodonite $(\mathrm{Mn})$. Frequent analysis of internal standards (chromite, magnetite, ilmenite, and rutile) and reanalysis of mineral standards used for calibration provided the basis for a drift correction and cross calibration between analyses from different days. Standard checks account for nearly one-third of the total number of analyses $(\sim 1100)$, providing a data set that should be internally consistent. Microprobe analyses were generally made on specific grains identified during reflected light observations and keyed to specific features on photomicrographs.

Paleomagnetic measurements were made on approximately 340 minicore samples, including analyses on board the JOIDES Resolution and in the paleomagnetic laboratories at LDEO and the Ocean Research Institute (ORI), University of Tokyo. All samples were subjected to either stepwise alternating field $(\mathrm{AF})$ or thermal demagnetization. AF demagnetization during Leg 144 and at LDEO utilized a Schonstedt (Model GSD-1) demagnetizer. At alternate steps, the samples were demagnetized along opposite axial directions to facilitate recognition of any spurious magnetization introduced during demagnetization. A tumbling-specimen demagnetizer was used for all AF demagnetization at the ORI. Samples at the ORI were thermally demagnetized using a Schonstedt oven; samples at LDEO were demagnetized using a large capacity oven with an ambient field of $<5-8 \mathrm{nT}$. Samples were measured at LDEO using a 2-G Enterprises cryogenic magnetometer housed in a shielded room. Remanence measurements on board the JOIDES Resolution were also made with a $2 \mathrm{G}$ magnetometer. Shore-based paleomagnetic measurements at the ORI were made on a Schonstedt digital spinner magnetometer (Model DSM-2). Curie temperatures were determined for approximately 65 samples, using a horizontal translation Curie balance at LDEO. Small samples $(\sim 50 \mathrm{mg})$ were heated in air at a rate of $25^{\circ} \mathrm{C} / \mathrm{min}$, with Curie temperatures determined graphically using the method of Grommé et al. (1969).

\section{OXIDE MINERALOGY}

The distribution of oxide phases in the mildly to strongly alkalic lavas sampled during Leg 144 is summarized in Table 1. The oxide minerals investigated include a variety of spinels (from chrome spinel to titanomagnetites and rare occurrences of magnesioferrite) and members of the hematite-ilmenite solid solution series, as well as alteration products in the pseudobrookite series. Typical textural and alteration relationships are illustrated in Plates 1 and 2, and representative mineral analyses are given in Tables 2-5. The locations of microprobe spot or raster analyses are indicated on the corresponding photomicrographs whenever applicable. The following sections describe the original oxide mineralogy, insofar as it can be reconstructed, and the alteration history of samples from Leg 144.

Alteration of iron-titanium oxides has typically been described in terms of low-temperature $\left(<150^{\circ} \mathrm{C}\right)$, hydrothermal $\left(\sim 150-400^{\circ} \mathrm{C}\right)$, or high-temperature $\left(>600^{\circ} \mathrm{C}\right)$ oxidation processes (e.g., Haggerty, 1976; Johnson and Hall, 1978; Pariso and Johnson, 1991). Apart from the occurrence of secondary hematite, evidence for hydrothermal alteration (e.g., granulation; Ade-Hall et al., 1971) in samples from Leg 144 is rare. The curvilinear shrinkage cracks and higher reflectivity indicative of low-temperature maghemitization were noted in several samples; however, the degree of low-temperature alteration is typically low (Stage 2 or 3 of Johnson and Hall, 1978). For this reason, and because some degree of high-temperature alteration is to be expected in these predominantly subaerially erupted lavas, we have developed a simplified alteration classification scheme that focuses on the higher temperature alteration categories.

The degree and type of alteration of oxide minerals was qualitatively estimated for each thin section. We have defined the following four alteration categories, based largely on the low-temperature alteration classification of Johnson and Hall (1978) and the high-temperature classification system $(\mathrm{C} 1-\mathrm{C} 7$ for spinel oxidation; $\mathrm{R} 1-\mathrm{R} 7$ for discrete ilmenite oxidation) of Haggerty $(1976,1991)$ :

LT: Predominantly low-temperature oxidation. Titanomagnetites exhibit moderate to extensive development of shrinkage cracks, with minor silicate replacement in some grains (Stages 2-4 of Johnson and Hall, 1978). This category also includes rare samples in which the titanomagnetites are nearly pristine (i.e., Stage 1 of Johnson and Hall, 1978, or equivalently, C1 grains in the high-temperature classification of Haggerty, 1976).

H1: Low degree of high-temperature oxidation. Titanomagnetite grains have a small number of ilmenite lamellae (C2). Discrete ilmenite grains are typically fresh (R1).

$\mathrm{H} 2$ : Moderate degree of high-temperature oxidation. This category includes $\mathrm{C} 3$ titanomagnetite grains, with abundant ilmenite lamellae, and C4 grains in which ilmenite lamellae have a mottled appearance on account of the fine-scale development of ferrirutile. Discrete ilmenite grains typically have moderate to extensive development of ferrirutile lenses in a ferrian ilmenite host (R2/R3).

$\mathrm{H} 3$ : Extensive high-temperature oxidation. This category includes titanomagnetite-ilmenite intergrowths corresponding to C5C7 grains in the classification of Haggerty (1976). Titanomagnetite grains are completely pseudomorphed by titanohematite + rutile (C5), with the appearance of pseudobrookite in the more advanced oxidation stages. Discrete ilmenite grains have abundant ferrirutile lenses, with the further replacement of ilmenite by titanohematite and pseudobrookite in more altered grains (R4 and higher).

\section{Chrome Spinel}

Chrome spinels are ubiquitous in the basanitic samples from Site 871 and the single ankaramitic flow sampled at Hole 874B and occur throughout much of the $200 \mathrm{~m}$ section sampled at Site 878 (Table 1). The absence of chrome spinels in samples from the remaining sites is generally compatible with the more evolved nature of these lavas (e.g., Thy, 1983). Chrome spinels occur primarily as subhedral to euhedral grains enclosed in olivine (occasionally in clinopyroxene) or as the cores of larger groundmass titanomagnetite grains (Plate 1A). A small number of grains are interpreted as xenocrysts based on the rounded outline, sharp contact with the mantling titanomagnetite, 
Table 1. Summary of oxide mineralogy and alteration.

\begin{tabular}{|c|c|c|c|c|c|c|c|c|c|c|c|c|}
\hline \multirow{2}{*}{$\begin{array}{l}\text { Core, section, } \\
\text { interval }(\mathrm{cm})\end{array}$} & \multirow{2}{*}{$\begin{array}{c}\text { Flow } \\
\text { unit }\end{array}$} & \multirow[b]{2}{*}{ Rock type } & \multicolumn{5}{|c|}{ Mineralogy } & \multirow{2}{*}{$\begin{array}{c}\text { Composition } \\
\left(x^{\prime}\right)\end{array}$} & \multirow{2}{*}{ Alteration } & \multicolumn{3}{|c|}{ Curie temperature } \\
\hline & & & Crsp. & $11 \mathrm{~m}$. & $\mathrm{TM}$ & Hem. & MF & & & Type & $\mathrm{Tc}$ & $\mathrm{Mf} / \mathrm{Mo}$ \\
\hline \multicolumn{13}{|l|}{ 144-871C- } \\
\hline $35 \mathrm{R}-1,32-34$ & 1 & Basanite & $\mathrm{x}$ & In $\mathrm{CPX}$ & $\mathrm{x}$ & $\mathrm{x}$ & & $78-91$ & LT & I & 285 & 1.46 \\
\hline $36 \mathrm{R}-1,58-60$ & $9 \mathrm{a}$ & Basanitoid & $\hat{x}$ & mern & $\hat{x}$ & $\lambda$ & & $76-83$ & LT/HI & I & 285 & 1.28 \\
\hline $36 \mathrm{R}-2,99-101$ & 13 & Basanitoid & $\hat{x}$ & & $\hat{x}$ & & & $78-90$ & LT & i & 270 & 1.36 \\
\hline $38 \mathrm{R}-2,104-106$ & 17 & Basanite & $\mathrm{x}$ & & $\mathrm{x}$ & $\mathrm{x}$ & & $72-82$ & LT & III & $240(505)$ & 1.57 \\
\hline $38 \mathrm{R}-6,13-15$ & 19 & Basanite & $\mathrm{x}$ & & $\hat{x}$ & $\mathrm{x}$ & & $72-91$ & LT & III & $220(465)$ & 1.82 \\
\hline $39 \mathrm{R}-2,46-48$ & $21 \mathrm{a}$ & Basanite & $x$ & & $\mathrm{x}$ & $\mathrm{x}$ & & $75-84$ & LT & & & \\
\hline \multicolumn{13}{|l|}{ 144-872B- } \\
\hline $5 \mathrm{R}-1.26-28$ & 6 & Diff. $A O B$ & & $\mathrm{x}$ & $\mathrm{x}$ & $\mathrm{x}$ & & $69-84$ & LT & 1 & 255 & 1.47 \\
\hline $5 R-3,11-13$ & $9 \mathrm{a}$ & Hawaiite & & $\mathrm{x}$ & $\mathrm{x}$ & $\mathrm{x}$ & & $79-80$ & $\mathrm{H} 2 / \mathrm{H} 3$ & IV & (385) 615 & 0.35 \\
\hline $5 R-4,70-72$ & $10 \mathrm{~b}$ & $\mathrm{AOB}$ & & $\hat{x}$ & $\hat{x}$ & $\hat{x}$ & & $40-73$ & $\mathrm{H} 2$ & IV & 585 & 0.41 \\
\hline $7 \mathrm{R}-1,9-11$ & 13 & $\mathrm{AOB}$ & & $\hat{x}$ & $\hat{x}$ & $\mathrm{~A}$ & & $90-92$ & $\mathrm{H} 2 / \mathrm{H} 3$ & IV & (385) 575 & 0.41 \\
\hline $7 \mathrm{R}-4,125-127$ & $14 \mathrm{~b}$ & Diff. $\mathrm{AOB}$ & & $\begin{array}{l}x \\
x\end{array}$ & $\begin{array}{l}x \\
x\end{array}$ & & & $45-58$ & $\mathrm{H} 2$ & IV & (280) 570 & 0.51 \\
\hline $7 R-7,54-56$ & $15 \mathrm{~b}$ & $\mathrm{AOB}$ & & $x$ & $\hat{x}$ & $x$ & & $90-100$ & $\mathrm{H} 2 / \mathrm{H} 3$ & IV & (290) 565 & 0.77 \\
\hline $8 R-2,139-141$ & $16 \mathrm{~b}$ & Diff. $A O B$ & & $x$ & $x$ & $x$ & & $42-66$ & LT & III & (290) 550 & 0.77 \\
\hline $9 \mathrm{R}-3,34-36$ & $17 \mathrm{~b}$ & Hawaiite & & $\hat{x}$ & $\hat{x}$ & $\mathrm{x}$ & & $77-88$ & LT/HI & II & 585 & 0.84 \\
\hline \multicolumn{13}{|l|}{$144-872 \mathrm{C}$} \\
\hline $18 X-1.95-97$ & 1 & Diff. $\mathrm{AOB}$ & & $\mathrm{x}$ & $\mathrm{x}$ & $\mathrm{x}$ & & $76-100$ & LT & III & $430(585)$ & 1.29 \\
\hline 144-873A- & & & & & & & & & & & & \\
\hline $17 \mathrm{R}-1,36-38$ & 5 & Basalt & & & $\mathrm{x}$ & $\mathrm{x}$ & & & $\mathrm{H} 3$ & IV & 585 & 0.51 \\
\hline $17 \mathrm{R}-1,50-52$ & 6 & Aphyric basalt & & & $\hat{x}$ & $\hat{x}$ & & & $\mathrm{H} 3$ & IV & 575 & 0.45 \\
\hline $18 \mathrm{R}-1,10-12$ & $8 ?$ & CPX basalt & & & $\hat{x}$ & & & $70-77$ & LT & $\mathrm{I}$ & 290 & 1.56 \\
\hline 144-874B- & & & & & & & & & & & & \\
\hline $23 \mathrm{R}-1,32-34$ & 1 & Ankaramite & $\mathrm{x}$ & & $\mathrm{x}$ & $x$ & & & H3* & IV & (410) 630 & 0.32 \\
\hline $24 \mathrm{R}-1,51-53$ & $i$ & Ankaramite & $\hat{x}$ & $\mathrm{x}$ & $\hat{x}$ & & & $72-86$ & $\mathrm{LT} / \mathrm{HI}$ & III & (300) 560 & 1.68 \\
\hline $24 \mathrm{R}-4,42-44$ & $\mathrm{i}$ & Ankaramite & $\hat{x}$ & $\hat{x}$ & $\hat{x}$ & & & $88-95$ & LT & 1 & 250 & 5.28 \\
\hline $144-875 \mathrm{C}-$ & & & & & & & & & & & & \\
\hline $15 \mathrm{M}-1,13-15$ & 1 & Olivine basalt & & $\mathrm{x}$ & $\mathrm{x}$ & $x$ & & $88-91$ & $\mathrm{LT}^{* * *}$ & III & (285) 605 & 0.97 \\
\hline $15 \mathrm{M}-1,72-74$ & 1 & Olivine basalt & & & & $\mathrm{x}$ & $\mathrm{x}$ & & $?$ & & & \\
\hline 144-876A- & & & & & & & & & & & & \\
\hline $15 \mathrm{R}-1,28-30$ & la & & & & $\mathrm{x}$ & $\mathrm{x}$ & $\mathrm{x}$ & $51-62$ & $\mathrm{H} 3$ & IV & (400) 570 & 0.19 \\
\hline $16 \mathrm{R}-1,78-80$ & 2 & Alkalic basalt & & & & $\mathrm{x}$ & $\mathrm{x}$ & & $?$ & & & \\
\hline $17 \mathrm{R}-1,7-9$ & 2 & Alkalic basalt & & & $\mathrm{x}$ & $\hat{x}$ & $\hat{x}$ & $44-45$ & ? & III & $310(615)$ & 0.95 \\
\hline 144-878A- & & & & & & & & & & & & \\
\hline $78 R-2,77-79$ & 1 & Hawaiite & & $x$ & $\mathrm{x}$ & $\mathrm{x}$ & & $60-87$ & $\mathrm{LT}^{* * *}$ & & & \\
\hline $79 \mathrm{R}-2.8-10$ & 2 & Hawaiite & $\mathrm{x}$ & $\mathrm{x}$ & $\mathrm{x}$ & $\mathrm{x}$ & & $59-81$ & $\mathrm{H} 2$ & III & (290) 550 & 1.18 \\
\hline $80 \mathrm{R}-3,28-30$ & 8 & Basanitoid & $\hat{x}$ & $\mathrm{x}$ & $\mathrm{x}$ & $\mathrm{x}$ & & $77-93$ & $\mathrm{H} 2$ & II & 575 & 0.80 \\
\hline $80 \mathrm{R}-5,2 \mathrm{I}-23$ & 8 & Basanitoid & $x$ & $\mathrm{x}$ & $\mathrm{x}$ & & & $78-89$ & LT & I & 250 & 2.49 \\
\hline $81 \mathrm{R}-3,30-32$ & 10 & Basanitoid & $x^{x}$ & $\mathrm{x}$ & $\begin{array}{l}x \\
x\end{array}$ & $\mathrm{x}$ & & $75-91$ & $\mathrm{H} 1 / \mathrm{H} 2$ & III & (300) 575 & 1.15 \\
\hline $8 \mid R-4,53-55$ & iI & Basanitoid & & $\hat{x}$ & $\hat{x}$ & $x$ & & & $\mathrm{H} 2$ & II & 575 & 0.74 \\
\hline $83 R-4,11-13$ & 13 & Olivine basalt & & Pyro. & $\hat{x}$ & & & $75-84$ & LT & I & 285 & 3.00 \\
\hline $84 R-4,67-69$ & 15 & Basanitoid & $\mathrm{x}$ & $\mathrm{x}$ & $\hat{x}$ & $\mathrm{x}$ & & $77-86$ & $\mathrm{H} 1 / \mathrm{H} 2$ & III & (235) 575 & 1.08 \\
\hline $84 \mathrm{R}-6,70-72$ & 15 & Basanitoid & $\hat{x}$ & & $\hat{x}$ & $\hat{x}$ & & $93-98$ & $\mathrm{H} 3^{*}$ & II & 565 & 0.87 \\
\hline $85 \mathrm{R}-1,142-144$ & 16 & Basanitoid & $\hat{x}$ & & $\hat{x}$ & $\hat{x}$ & & $88-95$ & LT & i & 290 & 1.03 \\
\hline $86 \mathrm{R}-3,39-41$ & 18 & Basanitoid & $\hat{x}$ & $\mathrm{x}$ & $\hat{x}$ & $\hat{x}$ & & $66-79$ & $\mathrm{H} 2 / \mathrm{H} 3$ & II & 585 & 1.26 \\
\hline $88 \mathrm{R}-3,64-66$ & 20 & Diff. AOB & $\hat{x}$ & & $\hat{x}$ & $\hat{x}$ & & $59-70$ & $\mathrm{H} 2$ & & & \\
\hline $89 R-3,75-77$ & 21 & Diff. $A O B$ & $\mathrm{x}$ & $\mathrm{x}$ & $\mathrm{x}$ & $\mathrm{x}$ & & $52-70$ & $\mathrm{H} 1$ & II & 580 & 1.01 \\
\hline $89 R-4,25-27$ & $2 i$ & Diff. $A O B$ & & $\hat{x}$ & $\hat{x}$ & $\hat{x}$ & & $59-60$ & $\mathrm{H} 2$ & III & (300) 575 & 1.11 \\
\hline $90 R-1,99-101$ & 21 & Diff. $A O B$ & & & $\hat{x}$ & $\hat{x}$ & & $55-70$ & $\mathrm{H} 2$ & & & \\
\hline $90 \mathrm{R}-2,40-42$ & 21 & Diff. AOB & $\mathrm{x}$ & & $x$ & 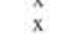 & & & $\mathrm{H} 3$ & III & (425) 585 & 2.75 \\
\hline $90 \mathrm{R}-4,115-117$ & 22 & $A O B$ & $\mathrm{x}$ & $\mathrm{x}$ & $\hat{x}$ & $\hat{x}$ & & $59-82$ & $\mathrm{H} 2 / \mathrm{H} 3$ & IV & (390) 590 & 1.93 \\
\hline 90R-5, 94-96 & 23 & Diff. $A O B$ & $\hat{x}$ & $\hat{x}$ & $\hat{x}$ & $\hat{x}$ & & 52 & $\mathrm{H} 3$ & III & (390) 590 & 3.23 \\
\hline $91 \mathrm{R}-1,97-99$ & 23 & Diff. $A O B$ & & $\mathrm{x}$ & $\mathrm{x}$ & $\hat{x}$ & & $42-49$ & $\mathrm{LT}^{* *}$ & II & 560 & 1.11 \\
\hline $9 \mid \mathrm{R}-3,86-88$ & 23 & Diff. AOB & $\mathrm{x}$ & $\hat{x}$ & $\hat{x}$ & & & $38-44$ & LT & $?$ & 510 & 0.87 \\
\hline $92 \mathrm{R}-2,73-75$ & 25 & $A O B$ & $\hat{x}$ & $\hat{x}$ & $\hat{x}$ & $x$ & $x$ & & $\mathrm{H} 3$ & IV & (330) 585 & 0.72 \\
\hline $92 \mathrm{R}-3,113-115$ & 26 & Diff. $\mathrm{AOB}$ & $\begin{array}{l}x \\
x\end{array}$ & $\begin{array}{l}x \\
x\end{array}$ & $\begin{array}{l}x \\
x\end{array}$ & $\begin{array}{l}x \\
x\end{array}$ & & $67-82$ & LT & III & (315) 510 & 1.17 \\
\hline $92 \mathrm{R}-5,36-38$ & 27 & Diff. AOB & & $\hat{x}$ & $\hat{x}$ & & & $65-79$ & LT & 1 & 300 & 2.11 \\
\hline $93 \mathrm{R}-1,21-23$ & 28 & $A O B$ & $\mathrm{x}$ & $\mathrm{x}$ & $\mathrm{x}$ & $\mathrm{x}$ & & $48-72$ & $\mathrm{H} 1 / \mathrm{H} 2$ & III & (335) 560 & 1.05 \\
\hline $94 \mathrm{R}-1,9-11$ & 30 & Diff. AOB-Haw. & $\hat{x}$ & $\hat{x}$ & $\hat{x}$ & $\hat{x}$ & & $54-62$ & $\mathrm{LT} / \mathrm{HI}$ & I & 300 & 1.20 \\
\hline $98 \mathrm{R}-3,88-90$ & 35 & Diff. $\mathrm{AOB}$ & $\hat{x}$ & $\hat{x}$ & $\hat{x}$ & & & $76-82$ & LT & i & 255 & 1.92 \\
\hline $144-879 \mathrm{~A}-$ & & & & & & & & & & & & \\
\hline $22 \mathrm{R}-3,129-131$ & 1 & Trans. basalt & & $\mathrm{x}$ & $x$ & & & $76-84$ & LT & 1 & 290 & 2.73 \\
\hline $22 \mathrm{R}-5,67-69$ & $i$ & Trans, basalt & & & $\hat{x}$ & & & 86 & LT & I & 260 & 3.85 \\
\hline
\end{tabular}

Notes: Rock types in italics are from shipboard petrographic description; the remaining names are from Christie et al. (this volume). $\mathrm{AOB}=$ alkali olivine basalt; Diff. $\mathrm{AOB}=$ differentiated alkali olivine basalt; Trans. basalt $=$ transitional basalt. $\mathrm{Cr}$ sp. $=$ chrome spinel, llm. $=$ ilmenite. TM $=$ titanomagnetite, Hem. $=$ hematite, $\mathrm{MF}=$ magnesioferrite, and Pyro. = pyrophanite. Titanomagnetite modified ulvöspinel content $\left(x^{\prime}\right)$ after Stormer (1983). Alteration categories are explained in the text. Curie temperature categories are explained in the text; subordinate Curie points are indicated in parentheses. Mf $/ \mathrm{Mo}=\mathrm{ratio}$ of final to initial magnetization. Single asterisk $(*)$ indicates that chrome spinels have been extensively altered; double asterisks $(* *)$ indicate that low-temperature alteration is dominant but with metailmenite. 
Table 2. Representative chrome spinel compositions.

\begin{tabular}{|c|c|c|c|c|c|c|c|c|c|c|c|c|c|}
\hline \multirow{3}{*}{$\begin{array}{l}\text { Hole: } \\
\text { Core, section: } \\
\text { Interval }(\mathrm{cm}) \text { : } \\
\text { Analysis: }\end{array}$} & \multicolumn{7}{|c|}{ Hole 87IC } & \multicolumn{4}{|c|}{ Hole 874B } & \multirow{2}{*}{\multicolumn{2}{|c|}{$\begin{array}{c}\text { Hole } 878 \mathrm{~A} \\
84 \mathrm{R}-6 \\
70\end{array}$}} \\
\hline & \multicolumn{4}{|c|}{$\begin{array}{c}38 \mathrm{R}-2 \\
104\end{array}$} & \multirow{2}{*}{$\begin{array}{c}\begin{array}{c}36 \mathrm{R}-2 \\
99\end{array} \\
58 \\
\text { Euh. }\end{array}$} & \multirow{2}{*}{$\begin{array}{c}\begin{array}{c}39 \mathrm{R}-2 \\
46\end{array} \\
59 \\
\text { Euh. }\end{array}$} & \multirow{2}{*}{$\begin{array}{c}36 \mathrm{R}-1 \\
58 \\
52 \\
\text { Core }\end{array}$} & \multirow{2}{*}{$\begin{array}{c}24 \mathrm{R}-4 \\
42 \\
70 \\
\text { Core }\end{array}$} & \multicolumn{3}{|c|}{$\begin{array}{c}24 \mathrm{R}-1 \\
51\end{array}$} & & \\
\hline & $\begin{array}{c}100 \\
\text { Plate 1B }\end{array}$ & $\begin{array}{c}91 \\
\text { Plate IB }\end{array}$ & $\begin{array}{c}95 \\
\text { Plate IB }\end{array}$ & $\begin{array}{c}113 \\
\text { Plate } 1 B^{*}\end{array}$ & & & & & $\begin{array}{c}32 \\
\text { Plate 1A }\end{array}$ & $\begin{array}{c}34 \\
\text { Plate IA }\end{array}$ & $\begin{array}{c}35 \\
\text { Plate 1A }\end{array}$ & $\begin{array}{l}133 \\
\text { Core }\end{array}$ & $\begin{array}{l}135 \\
\text { Euh. }\end{array}$ \\
\hline $\begin{array}{l}\mathrm{SiO}_{2} \\
\mathrm{TiO}_{2} \\
\mathrm{Al}_{2} \mathrm{O}_{3} \\
\mathrm{Cr}_{2} \mathrm{O}_{3} \\
\mathrm{Fe}_{2} \mathrm{O}_{3} \\
\mathrm{MgO} \\
\mathrm{MnO} \\
\mathrm{FeO} \\
\text { Total }\end{array}$ & $\begin{array}{r}0.03 \\
0.02 \\
24.46 \\
43.48 \\
3.15 \\
12.67 \\
0.00 \\
16.72 \\
100.53\end{array}$ & $\begin{array}{r}0.00 \\
0.08 \\
21.37 \\
42.82 \\
6.85 \\
12.15 \\
0.00 \\
16.88 \\
100.15\end{array}$ & $\begin{array}{r}0.04 \\
0.42 \\
7.65 \\
38.95 \\
21.51 \\
4.15 \\
0.00 \\
26.92 \\
99.64\end{array}$ & $\begin{array}{r}0.40 \\
1.25 \\
11.35 \\
47.34 \\
9.86 \\
10.64 \\
0.00 \\
19.07 \\
99.91\end{array}$ & $\begin{array}{r}0.11 \\
1.66 \\
27.46 \\
29.67 \\
11.71 \\
14.67 \\
0.00 \\
15.75 \\
101.03\end{array}$ & $\begin{array}{r}0.09 \\
2.77 \\
28.55 \\
22.04 \\
14.34 \\
11.70 \\
0.00 \\
21.33 \\
100.83\end{array}$ & $\begin{array}{r}0.07 \\
8.55 \\
17.26 \\
16.54 \\
18.06 \\
4.47 \\
0.22 \\
35.44 \\
100.62\end{array}$ & $\begin{array}{r}0.09 \\
4.85 \\
18.66 \\
26.91 \\
13.66 \\
7.57 \\
0.00 \\
27.47 \\
99.21\end{array}$ & $\begin{array}{r}0.09 \\
1.90 \\
21.06 \\
35.69 \\
9.22 \\
9.35 \\
0.00 \\
22.82 \\
100.14\end{array}$ & $\begin{array}{c}0.06 \\
2.43 \\
19.60 \\
34.302 \\
9.78 \\
6.76 \\
0.00 \\
26.88 \\
99.82\end{array}$ & $\begin{array}{r}0.03 \\
8.75 \\
8.66 \\
8.02 \\
14.90 \\
4.70 \\
0.00 \\
33.48 \\
98.54\end{array}$ & $\begin{array}{r}0.09 \\
2.88 \\
28.85 \\
22.37 \\
12.45 \\
11.41 \\
0.00 \\
21.55 \\
99.59\end{array}$ & $\begin{array}{r}0.09 \\
5.80 \\
22.80 \\
21.44 \\
12.93 \\
8.31 \\
0.00 \\
27.85 \\
99.20\end{array}$ \\
\hline $\begin{array}{l}\mathrm{Si} \\
\mathrm{Ti} \\
\mathrm{Al} \\
\mathrm{Cr}^{3+} \\
\mathrm{Fe}^{3+} \\
\mathrm{Mg} \\
\mathrm{Mn}^{2+} \\
\mathrm{Fe}^{2+} \\
\text { Cation sum }\end{array}$ & $\begin{array}{r}0.006 \\
0.004 \\
7.026 \\
8.377 \\
0.577 \\
4.602 \\
0.000 \\
3.407 \\
24.000\end{array}$ & $\begin{array}{r}0.000 \\
0.015 \\
6.266 \\
8.421 \\
1.283 \\
4.504 \\
0.000 \\
3.511 \\
24.000\end{array}$ & $\begin{array}{r}0.011 \\
0.089 \\
2.543 \\
8.689 \\
4.567 \\
1.747 \\
0.000 \\
6.353 \\
24.000\end{array}$ & $\begin{array}{r}0.106 \\
0.247 \\
3.513 \\
9.832 \\
1.949 \\
4.165 \\
0.000 \\
4.188 \\
24.000\end{array}$ & $\begin{array}{r}0.026 \\
0.296 \\
7.688 \\
5.573 \\
2.094 \\
5.193 \\
0.000 \\
3.129 \\
24.000\end{array}$ & $\begin{array}{r}0.022 \\
0.504 \\
8.130 \\
4.210 \\
2.608 \\
4.215 \\
0.000 \\
4.311 \\
24.000\end{array}$ & $\begin{array}{r}0.018 \\
1.714 \\
5.426 \\
3.487 \\
3.624 \\
1.778 \\
0.050 \\
7.903 \\
24.000\end{array}$ & $\begin{array}{r}0.024 \\
0.956 \\
5.767 \\
5.578 \\
2.696 \\
2.956 \\
0.000 \\
6.024 \\
24.000\end{array}$ & $\begin{array}{r}0.023 \\
0.363 \\
6.302 \\
7.165 \\
1.761 \\
3.540 \\
0.000 \\
4.846 \\
24.000\end{array}$ & $\begin{array}{r}0.015 \\
0.477 \\
6.023 \\
7.073 \\
1.919 \\
2.629 \\
0.000 \\
5.863 \\
24.000\end{array}$ & $\begin{array}{r}0.008 \\
1.854 \\
2.875 \\
6.242 \\
3.158 \\
1.974 \\
0.000 \\
7.888 \\
24.000\end{array}$ & $\begin{array}{r}0.021 \\
0.528 \\
8.298 \\
4.317 \\
2.287 \\
4.152 \\
0.000 \\
4.397 \\
24.000\end{array}$ & $\begin{array}{l}0.022 \\
1.118 \\
6.886 \\
4.342 \\
2.492 \\
3.173 \\
0.000 \\
5.967 \\
24.000\end{array}$ \\
\hline $\begin{array}{l}\mathrm{Mg \#} \\
\mathrm{Cr} \#\end{array}$ & $\begin{array}{l}57.46 \\
54.39\end{array}$ & $\begin{array}{l}56.19 \\
57.34\end{array}$ & $\begin{array}{l}21.57 \\
77.36\end{array}$ & $\begin{array}{l}49.86 \\
73.67\end{array}$ & $\begin{array}{l}62.40 \\
42.03\end{array}$ & $\begin{array}{l}49.44 \\
34.12\end{array}$ & $\begin{array}{l}18.36 \\
39.13\end{array}$ & $\begin{array}{l}32.92 \\
49.17\end{array}$ & $\begin{array}{l}42.21 \\
53.21\end{array}$ & $\begin{array}{l}30.96 \\
54.01\end{array}$ & $\begin{array}{l}20.02 \\
68.46\end{array}$ & $\begin{array}{l}48.56 \\
34.22\end{array}$ & $\begin{array}{l}34.71 \\
38.67\end{array}$ \\
\hline
\end{tabular}

Notes: Analysis spots shown in Plates 1 or 2 where indicated. ${ }^{*}=$ equivalent to vermicular region in photo. Euh. $=$ euhedral grain enclosed in olivine or pyroxene; Core $=$ chrome spinel core mantled by titanomagnetite. $\mathrm{Mg} \#=100 \cdot\left(\mathrm{Mg}^{2+} /\left[\mathrm{Mg}^{2+}+\mathrm{Fe}^{2+}\right]\right) . \mathrm{Cr} \#=100 \cdot(\mathrm{Cr} /[\mathrm{Cr}+\mathrm{Al}])$.

and distinctive compositions of the grains. For example, the large chrome spinel grain shown in Plate $\mathrm{IB}$ is distinctly more $\mathrm{Cr}$ rich $\left(\mathrm{Cr}_{2} \mathrm{O}_{3}=39 \%-44 \%\right)$ and $\mathrm{Al}$ poor than other grains within this sample $\left(\mathrm{Cr}_{2} \mathrm{O}_{3}=23 \%-24 \%\right)$ (Table 2). Chrome spinels within olivines are generally fresh (optically homogeneous) as are spinels in the cores of titanomagnetite grains, except in the most altered samples (alteration Stage $\mathrm{H} 3$ ).

Chrome spinels in samples from Leg 144 exhibit considerable compositional variability (Fig. 1 and Table 2), with near-continuous variation from chrome spinels with $\sim 1 \%-4 \% \mathrm{TiO}_{2}$ to titanomagnetites rich in $\mathrm{Al}, \mathrm{Mg}$, and $\mathrm{Cr}$. With few exceptions, the latter grains occur in rocks with $<8.0 \mathrm{wt} \% \mathrm{MgO}$ and are most common in lavas from Site 878. These $\mathrm{Al}-, \mathrm{Mg}-$, and $\mathrm{Cr}$-rich titanomagnetites generally occur as compositionally homogeneous euhedral grains enclosed in olivine or clinopyroxene, although similar compositions are found in zoned chrome spinel grains mantled by titanomagnetite (e.g., Sample 144$874 \mathrm{~B}-24 \mathrm{R}-1,51 \mathrm{~cm}$, in Table 2). The range of chrome spinel compositions shown in Figure 1 includes analyses from both these types of occurrences. Analyses from chrome spinel cores mantled by titanomagnetite may in some cases be biased toward higher $\mathrm{Ti}$ contents by partial overlap with the titanomagnetite grain. However, the similar compositional variation observed in euhedral grains suggests substantial compositional overlap between chrome spinels and titanomagnetites. Similar compositional continuity between $\mathrm{Cr}$-spinel and titanomagnetite has been noted in lavas from Suiko Seamount (Clague et al., 1980), although this variability was attributed, in part, to the reaction of partially enclosed chrome spinel grains with the groundmass.

With the exception of presumed xenocrystic grains, the compositions of chrome spinels from Leg 144 samples are compatible with the mildly to strongly alkalic nature of the host lavas. Alkalic lavas sampled from the Hawaiian-Emperor Chain (e.g., Clague et al., 1980) tend to have $\mathrm{Cr}<\mathrm{Al}$, whereas tholeiitic lavas are characterized by chrome spinels with $\mathrm{Cr}>\mathrm{Al}$. Spinels from basanitic samples recovered at Site 871 have lower chrome contents and higher ferric iron contents than the chrome spinels from Hole 874B (Fig. 1A), consistent with the less alkalic nature inferred for the latter site (Premoli Silva, Haggerty, Rack, et al., 1993; Christie et al., this volume). Chrome spinels from Site 878 span a range of compositions consistent with the more diverse bulk-rock compositions reported for these lavas. The high titanium content in Leg 144 spinels (Fig. 1B) is also consistent with the alkalic nature of the lavas. For comparison,
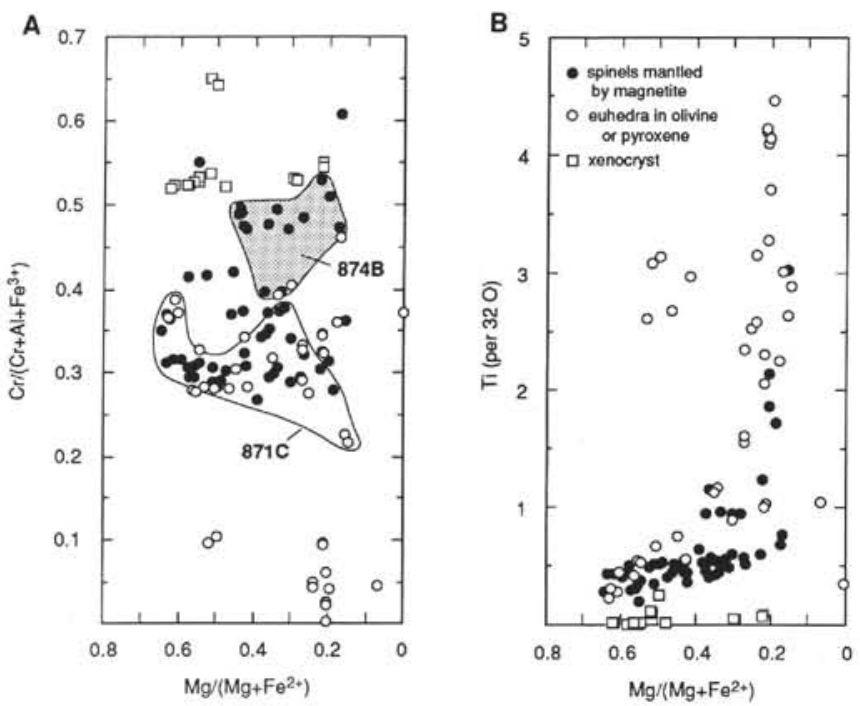

Figure 1. Compositional variations in chrome spinels from Leg 144 lavas. A. Magnesium number ( $\mathrm{Mg \# )}$ vs. chrome number ( $\mathrm{Cr} \#)$. The shaded (open) field includes all analyses from Hole 874B (Hole $871 \mathrm{C}$ ), although analyses from Hole 878 A overlap both fields. B. Mg\# vs. Ti content (calculated on the basis of 32 oxygens).

chrome spinels from mid-ocean-ridge tholeiites generally have $\mathrm{TiO}_{2}$ contents of $<2.0 \%$ (e.g., Sigurdsson and Schilling, 1976), with significantly lower contents $(0.16 \%-0.85 \%)$ reported from near-ridge seamounts (e.g., Allan et al., 1988).

\section{Titanomagnetite}

Titanomagnetite in samples from Leg 144 guyots occurs primarily as subhedral to euhedral, equant grains, although skeletal morphologies (e.g., Plate 1D) are present in some flows. For example, the amoeboidal pillow lavas (terminology of Staudigel and Schmincke, 1984) from Site 879 have predominantly fine-grained quench crystals, consistent with the inferred rapid cooling of these lavas. The 


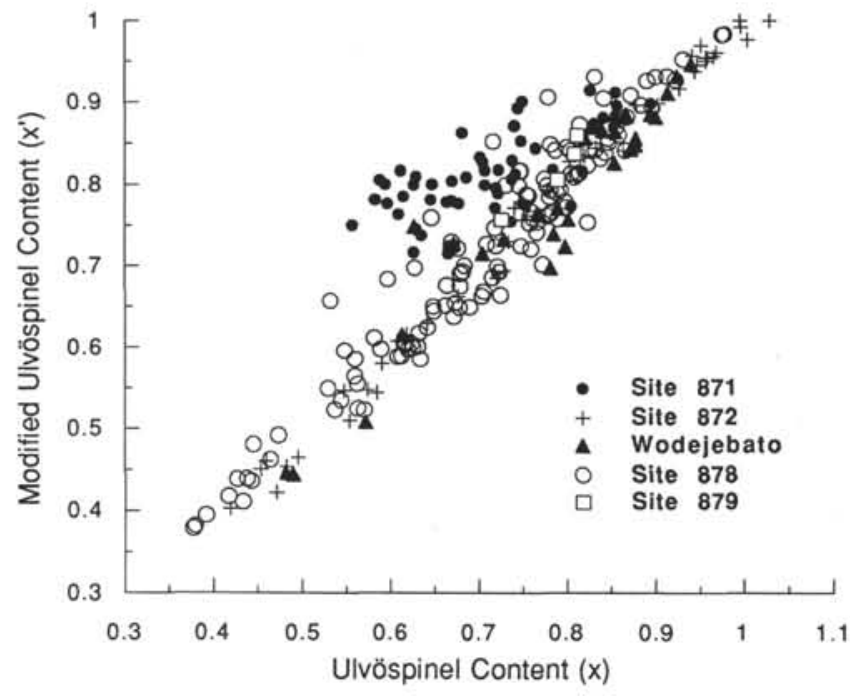

Figure 2. Ulvöspinel content $(x)$ vs. modified ulvöspinel $\left(x^{\prime} ;\right.$ Stormer, 1983) of titanomagnetites from Leg 144. See text for definitions of $x$ and $x^{\prime}$.

paucity of skeletal grains, together with the relatively large grain size and evidence for high-temperature oxidation, is compatible with the subaerial origin inferred for most lavas sampled during Leg 144 (Premoli Silva, Haggerty, Rack, et al., 1993). Titanomagnetite also occurs in intimate intergrowths with ilmenite, occasionally as elongate, external composite intergrowths (cf. Haggerty, 1976) that are clearly of magmatic origin (Plate $1 \mathrm{E}$ ). In other cases, the intergrowths are patches (Plate 1E), with either magnetite or ilmenite as the host phase. The origin of these internal composite intergrowths is uncertain (Haggerty, 1976). The occurrence of ilmenite patches in titanomagnetites with no evidence of oxyexsolution and the presence of small magnetite patches in otherwise homogeneous ilmenite grains, however, suggest a magmatic origin for the bulk of the composite intergrowths in the present sample collection.

The compositional variation of titanomagnetites is large, spanning a considerable portion of the magnetite-ulvöspinel solid solution series (Fig. 2). The majority of analyses summarized in this figure are from optically homogeneous grains, although a significant number of reconstructed compositions (raster analysis of grains with oxyexsolution lamellae) are also included. The ulvöspinel content $(x$, where $x=$ $\left.100 \cdot 3 \mathrm{Ti} /\left[\mathrm{Ti}+\mathrm{Fe}_{\text {tot }}\right]\right)$ ranges from 30 to values slightly over 100 . These high values are probably a reflection of both the significant amount of "minor" elements (which may equal or even exceed the cation proportion of Ti; e.g., Sample 144-871C-38R-6, 13-15 cm, in Table 3 ) and iron loss presumably associated with low-temperature alteration. Modified ulvöspinel contents ( $x^{\prime}$; Stormer, 1983), which incorporate minor elements, may be either higher or lower than the corresponding $x$ value depending on the distribution of these minor elements. Substitution of $\mathrm{Al}$ and $\mathrm{Cr}$ for $\mathrm{Fe}^{3+}$ in octahedral coordination results in higher effective ulvöspinel contents. The magnitude of this effect is particularly evident in the $\mathrm{Al}$ - and $\mathrm{Cr}$-rich titanomagnetites from Site 871, which are displaced significantly toward higher $x^{\prime}$ values (Fig. 2). Conversely, $\mathrm{Mg}$ - and $\mathrm{Mn}$-rich titanomagnetites yield lower $x^{\prime}$ values because these elements are assumed to substitute for tetrahedrally coordinated $\mathrm{Fe}^{2+}$.

Many of the titanomagnetite analyses yield low totals (Table 3) when structural formulae are calculated on the assumption of stoichiometry. We have no particular reason to doubt the validity of these analyses. Other titanomagnetites or additional oxide phases analyzed in the same microprobe session yield totals near $100 \%$. Although some low totals might be attributed to small grain sizes or to the presence of unanalyzed elements (e.g., vanadium), cation deficiency provides a plausible explanation for the low analytical totals. Iron loss and the
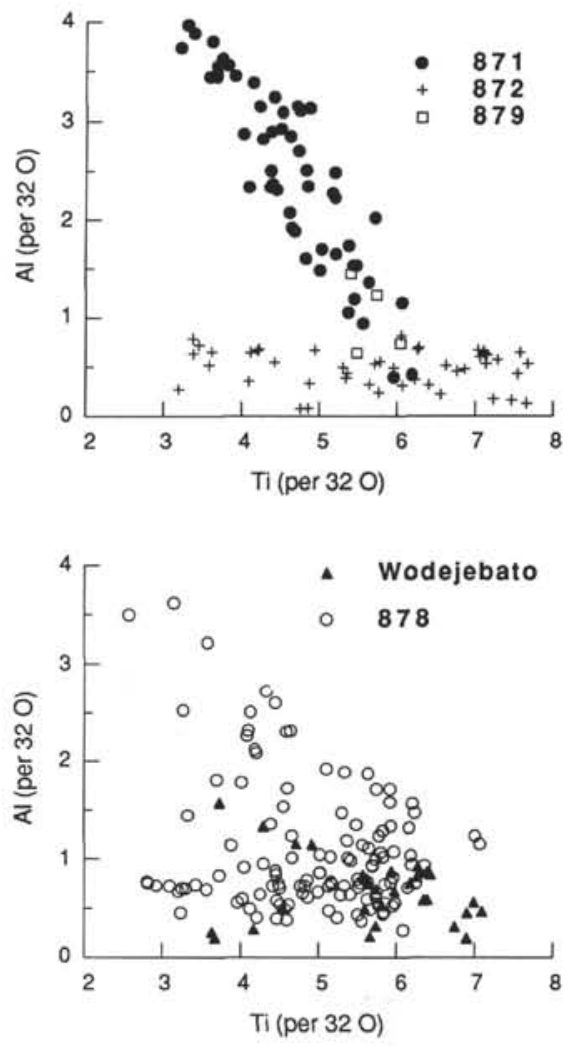

Figure 3. Aluminum content vs. titanium content (on the basis of 32 oxygens) for titanomagnetites from Leg 144 samples.

concomitant cation deficiency associated with low-temperature maghemitization will contribute to higher ulvöspinel contents, whether calculated from only the $\mathrm{Fe} / \mathrm{Ti}$ ratio or under the assumption of minor element substitution. The maximum $\mathrm{TiO}_{2}$ content $(\sim 30 \%$, corresponding to an ideal stoichiometric titanomagnetite with an $x$ value of $\sim 85$ ) and low analytical totals of samples from Leg 144 are consistent with some degree of cation deficiency. Titanomagnetite analyses with $x>$ 90 in Figure 2 all have low analytical totals $<95 \%$ after calculation of $\mathrm{Fe}^{3+}$ on the basis of charge balance, providing further support for this interpretation.

The aluminum content of titanomagnetites (Fig. 3) provides an indication of the degree of silica undersaturation of the host lavas (e.g., Frost and Lindsley, 1991); however, it also exerts an important control on the magnetic properties. In particular, increased Al substitution results in a significant decrease in Curie temperature (Özdemir and Moskowitz, 1992). The basanitic lavas from Site 871 have titanomagnetites, which are extremely rich in $\mathrm{Al}_{2} \mathrm{O}_{3}$, as might be expected from the highly silica-undersaturated nature of the lavas. $\mathrm{Al}_{2} \mathrm{O}_{3}$ contents in these lavas reach $12 \%(\sim 4 \mathrm{Al}$ per 24 cations $)$, comparable to values in titanomagnetites from other strongly alkalic lavas (e.g., Kyle, 1981). Titanomagnetites from Wodejebato (Sites 873-877) and Lo-En (Site 872 ) guyots generally have $\mathrm{Al}$ contents $(0.25-1.0 \mathrm{Al}$ per 24 cations) that are significantly lower than those measured from Site 871 titanomagnetites. These lower $\mathrm{Al}_{2} \mathrm{O}_{3}$ contents $(0.75 \%-3.0 \%)$ are compatible with the slightly alkalic nature of these lavas, and are somewhat higher those typically found in mid-ocean-ridge tholeiites (1\%-2\%; e.g., Perfit and Fornari, 1983). The five samples from Wodejebato Guyot with slightly higher aluminum contents (up to 1.5 $\mathrm{Al}$ per 24 cations) are from titanomagnetites that mantle more aluminous chrome spinels or are residual spinels in more highly oxidized grains (Table 3 and Plates 2C-2D). Titanomagnetite compositions from Site 878 exhibit a wide range of aluminum contents. The majority of titanomagnetites from MIT Guyot have moderate aluminum 


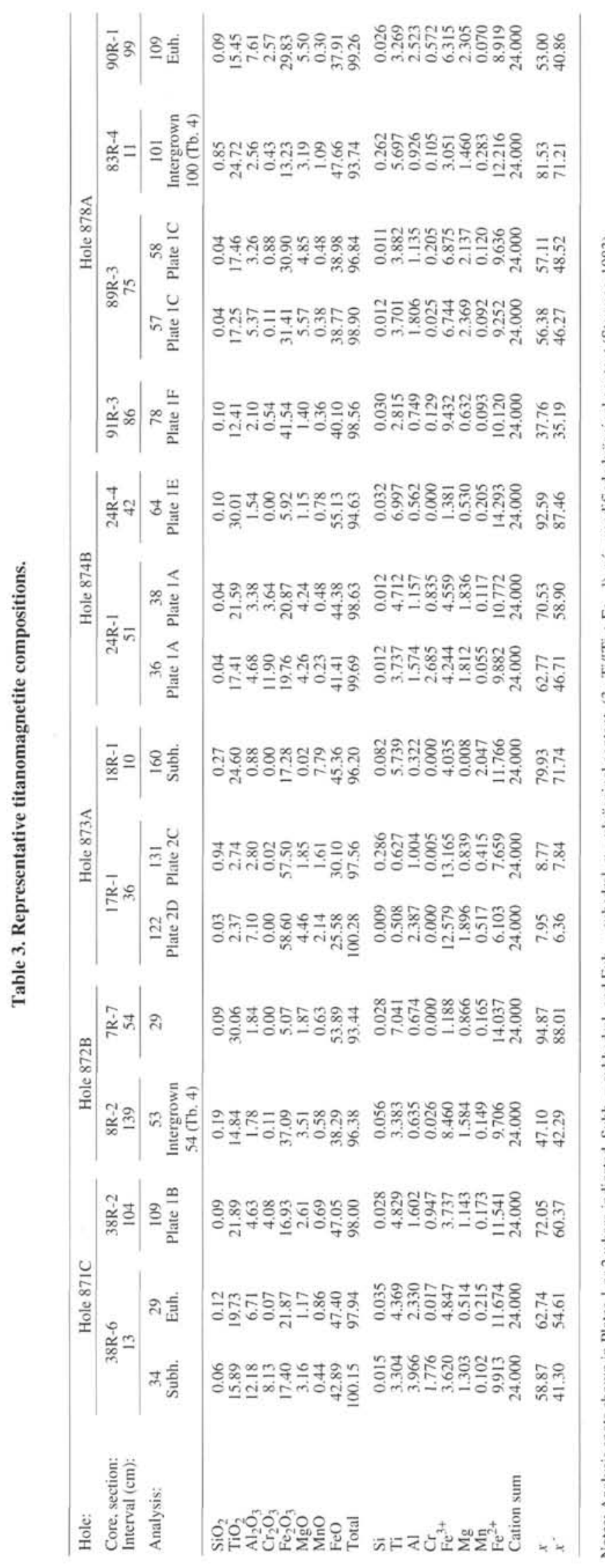

contents $(<1 \mathrm{Al}$ per 24 cations) consistent with the mildly alkalic nature of the lavas. Higher $\mathrm{Al}$ contents are more prevalent in the basanitic and hawaiitic lavas from the upper portion of the section (Table 1). Although some of the most aluminum-rich compositions from Site 878 are from titanomagnetites mantling chrome spinels, the majority of the $\mathrm{Al}$-rich grains (up to $11 \% \mathrm{Al}_{2} \mathrm{O}_{3}$ ) are euhedral titanomagnetites. These euhedral grains generally have $\mathrm{Cr}_{2} \mathrm{O}_{3}<2 \%$, in contrast to the Ti-rich chrome spinel euhedra that also occur in these lavas (cf., Analysis 109 in Table 3 and analyses in Table 2).

Titanomagnetites from the alkalic lavas sampled during Leg 144 are also relatively enriched in additional minor elements $(\mathrm{Mg}, \mathrm{Cr}$, and $\mathrm{Mn})$. The $\mathrm{MgO}$ contents generally co-vary with $\mathrm{Al}_{2} \mathrm{O}_{3}$, with values as high as $6 \%$ in the basanitic lavas from Site 871 . High $\mathrm{MgO}$ contents are also favored by low silica activity in the melt (Frost and Lindsley, 1991), consistent with the generally alkalic nature of the lavas. The extremely low $\mathrm{MgO}$ contents in some titanomagnetites and the variability of magnesium content within a single polished thin section may reflect, in part, subsolidus re-equilibration (e.g., Bacon and Hirschmann, 1988). It is interesting to note, however, that some of the lowest $\mathrm{MgO}$ contents occur in low-temperature altered samples (e.g., Analysis 160 in Table 3), suggesting that the processes responsible for magnesium loss may be operative down to quite low temperatures. The $\mathrm{Cr}_{2} \mathrm{O}_{3}$ contents of titanomagnetites also exhibit extreme variability within some samples (e.g., Sample 144-871C-38R-6, 13-15 cm, in Table 3). In most cases, the smaller grains have lower $\mathrm{Cr}_{2} \mathrm{O}_{3}$ contents than larger grains or titanomagnetites mantling chrome spinels, presumably reflecting the depletion of $\mathrm{Cr}$ during fractionation.

The range of titanomagnetite alteration textures encountered in Leg 144 lavas is illustrated in Plates 1 and 2. Low-temperature alteration, with the associated development of shrinkage cracks and higher reflectivity (Plate 1D), is the dominant type of alteration in samples from Sites 871 and 879 , as well as in several flows (particularly in the lower portion) of Site 878 (Table 1). Evidence for a limited amount of high-temperature oxidation is also found in many of these samples, suggesting that low-temperature oxidation may overprint the deuteric oxidation in many cases. This suggestion seems reasonable in view of the prolonged exposure to seawater that the flows must have experienced during initial subsidence of the guyots. This interpretation is further supported by the generally low analytical totals for titanomagnetites and the presence of irreversible Curie temperature curves for some samples that have clear evidence of high-temperature oxyexsolution.

High-temperature oxidation is the predominant type of alteration in most samples, with a textural progression that is adequately described by the high-temperature alteration sequence outlined by Haggerty (1976). Oxyexsolution results in the development of ilmenite lamellae along $\langle 111\rangle$ planes in the host titanomagnetite grain, with the trellis ilmenite lamellae becoming increasingly abundant as oxidation progresses. Further oxidation results in a mottled appearance of the titanomagnetite-ilmenite intergrowths ( $\mathrm{C} 4$ grains; Plate $2 \mathrm{~A}$ ), as a result of the development of fine-scale ferrirutile in metailmenite and submicroscopic spinel exsolution in the host titanomagnetite (Haggerty, 1976). The subsequent alteration stage (C5) is illustrated in Plate 2B, where the titanomagnetite-ilmenite intergrowth has been nearly completely replaced by an assemblage of hematite + rutile. Raster microprobe analyses of similarly oxidized grains yield Ti-rich compositions nearly identical to adjacent less oxidized grains (Plate $1 \mathrm{C}$ and Table 3 ), confirming the essentially isochemical nature of the oxidation. However, analyses from highly oxidized grains have low totals when recalculated as spinels, with totals nearer $100 \%$ when recalculated as titanohematites.

Higher degrees of alteration (C6-C7 of Haggerty, 1976), as evidenced by the formation of pseudobrookite and titanohematite assemblages with occasional magnesioferrite development, occur in a relatively small number of samples from Leg 144 . Particularly welldeveloped textures are evident in samples from a volcanic bomb (Sample 144-873A-17R-1, 50-52 cm) and from adjacent highly oxi- 
dized samples within Hole $873 \mathrm{~A}$. These samples also serve to illustrate the effect of high original $\mathrm{Mg}$ and $\mathrm{Al}$ contents in stabilizing the titanomagnetites even under high degrees of alteration (cf. Haggerty, 1976). The grain in Plate $2 \mathrm{C}$ illustrates the development of titanohematite and pseudobrookite lamellae in a host titanomagnetite grain with spinel exsolution lamellae and local martitization. Another grain from this same sample (Plate 2D) has coarse titanohematite lamellae developed at the margins of the residual titanomagnetite. In both cases, the titanomagnetite is $\mathrm{Ti}$ poor but with relatively high $\mathrm{Al}_{2} \mathrm{O}_{3}$ and $\mathrm{MgO}$ contents (Table 3 ). Compositions of the coexisting titanohematite and pseudobrookite grains are given in Table 4. Although the pseudobrookite minerals in most samples are pseudobrookites (sensu stricto) according to the classification scheme of Bowles (1988), minerals more properly termed armalcolite occur in other samples (e.g., Analysis 79 in Table 4).

\section{Ilmenite-Hematite}

Ilmenite-rich members of the ilmenite-hematite solid solution series occur primarily as groundmass laths, exsolution lamellae in titanomagnetites, and in composite intergrowths with titanomagnetite. Ilmenite is notably absent from the basanitic lavas recovered at Site 871 , consistent with the inferred presence of modal nepheline (Premoli Silva, Haggerty, Rack, et al., 1993) in many of these lavas (Frost and Lindsley, 1991). Although ilmenite is lacking as a groundmass phase in these lavas, it does occur as an inclusion in clinopyroxene in at least one sample. This ilmenite inclusion has among the highest $\mathrm{MgO}$ contents found in the sample collection (Analysis 20 in Table 5). The majority of ilmenite grains have $\mathrm{MgO}$ contents ranging from $0.5 \%$ to $7.0 \%$, compatible with the alkalic nature of the lavas. By comparison, tholeiitic lavas typically have ilmenites with $1 \%-3 \%$ $\mathrm{MgO}$ (e.g., Haggerty, 1976), although Cawthorn and Biggar (1993) have recently demonstrated that more magnesian ilmenites may crystallize from tholeiitic lavas depending on the $\mathrm{MgO}$ content of the melt when ilmenite saturation is reached. The only other significant minor component in most of the ilmenites is $\mathrm{MnO}$, which generally ranges from $0.5 \%$ to $1.5 \%$ (Table 5). Substantially higher $\mathrm{MnO}$ contents in some ilmenite exsolution lamellae within titanomagnetites (Plate 2A and Analysis 135 in Table 5) may reflect subsolidus re-equilibration (Rumble, 1976).

Mn-rich ilmenite occurs in a single sample from Site 878 (Sample 144-878A-83R-4, 11-13 cm). The pyrophanite-rich ilmenite (Table 5) in this sample occurs primarily as discrete groundmass grains and in composite intergrowths with ulvöspinel-rich titanomagnetite (Analysis 101 in Table 3). Although some Mn enrichment may occur during subsolidus re-equilibration, such extreme enrichment (to $25 \% \mathrm{MnO}$ ) is difficult to envision. The lack of high-temperature oxidation features in the associated titanomagnetite grains, as well as the shape of the ilmenite laths, is suggestive of a magmatic, rather than an alterationrelated, origin for these intergrowths. Furthermore, the occurrence of similar ilmenite-rich grains completely enclosed in olivine (Analysis 107 in Table 5) strongly suggests that the pyrophanite-rich ilmenites in this sample are of primary magmatic origin. Ilmenites with similarly high $\mathrm{MnO}$ contents are relatively rare, although they are known to occur in lamproites, lamprophyres, carbonatites, and peralkaline rock types (Tompkins and Haggerty, 1985). Although such Mn-rich compositions are uncommon in alkaline rocks, a pyrophanite-rich ilmenite ( $29 \% \mathrm{MnO}$ ) has been reported from a nepheline-syenite inclusion from Tenerife, Canary Islands (Ferguson, 1978). No whole-rock geochemical data is available for Sample 144-878A-83R-4, 11-13 cm, which is taken from a flow unit identified as an olivine basalt based on shipboard petrographic observations. More detailed characterization of the silicate mineralogy and bulk-rock geochemistry will be the subject of further study.

Discrete ilmenite grains from samples exhibiting only low-temperature or limited high-temperature alteration of titanomagnetite (category $\mathrm{Hl}$ samples) are generally fresh. Development of ferrirutile lamellae (Plate 2E), particularly along cracks or at grain margins, is common in samples from higher alteration stages. The majority of altered ilmenite grains from the present sample collection show primarily ferrirutile development and would be classified as R2/R3 in the high-temperature alteration scheme of Haggerty (1976). Alteration to titanohematite (Plate 2E and Analysis 101 in Table 5) characteristic of higher degrees of alteration (R4 and above) is less common, and pseudobrookite replacement of discrete ilmenite grains was noted in only a few samples.

In addition to the occurrence of titanohematite as an alteration product of titanomagnetite discussed above, Ti-poor titanohematite occurs in most of the samples from Leg 144 (Table 1). The majority of these titanohematites have $\mathrm{TiO}_{2}$ contents of $\sim 0 \%-2 \%$, with minor amounts of $\mathrm{Al}_{2} \mathrm{O}_{3}$ and $\mathrm{Cr}_{2} \mathrm{O}_{3}$ (Table 4). These Ti-poor titanohematites occur as discrete prismatic grains in the groundmass or as veins within, or along the margins of, ilmenite or titanomagnetite grains. The prismatic habit and essentially Ti-free compositions of some grains (e.g., Analysis 116 in Table 4) suggest an origin as a hydrothermal precipitate (Ramdohr, 1969). The apparent continuation of hematite veins from the interior of magnetite or ilmenite grains into the groundmass strongly supports a hydrothermal origin for these occurrences as well. The origin of Ti-poor titanohematites, which are often intimately associated with magnetite or ilmenite grains (e.g., Plate 2E), is uncertain. They may be either of hydrothermal origin or might conceivably represent total replacement of preexisting ilmenite or titanomagnetite grains. However, where titanohematite pseudomorphs after titanomagnetite can be recognized from the presence of relict ilmenite exsolution textures, these grains invariably contain significant amounts of $\mathrm{TiO}_{2}$ (typically $15 \%-20 \%$ ). The presence of substantial $\mathrm{TiO}_{2}$ in these pseudomorphic grains suggests that many of the Ti-poor hematites in these samples may be products of hydrothermal alteration.

\section{Magnesioferrite}

Magnesioferrite occurs both as an alteration product of titanomagnetite grains and as well-formed discrete grains associated with Tipoor titanohematite (Plate 2F). Magnesioferrite grains that formed as an exsolution product of highly altered, $\mathrm{Al}$-rich titanomagnetites typically have significant $\mathrm{Fe}^{2+}$ contents (i.e., pleonaste-magnesioferrite solid solutions) and are associated with pseudobrookite and $\mathrm{Mg}$-rich titanohematite (Haggerty, 1976). By contrast, nearly pure magnesioferrite associated with titanohematite was noted in samples from Sites 875 and 876 on Wodejebato Guyot (Table 4). In these samples, subhedral to anhedral discrete magnesioferrite and hematite grains occur primarily along vesicle margins or in flow-top breccias. The origin of the magnesioferrite in these samples is uncertain, although fumarolic activity in magnesium-rich host rocks is a possible candidate (e.g., Hurlbut and Klein, 1977). It is interesting to note that magnesioferrite was found as a major constituent in the Campanian clay unit overlying volcanic basement at Site 873 (Kemp, 1993), although no petrographic evidence of magnesioferrite was noted in the volcanic units sampled at this site (Table 1).

\section{MAGNETIC PROPERTIES Natural Remanent Magnetization and Königsberger Ratio}

The most relevant magnetic parameters for comparison with seasurface magnetic anomaly data are the natural remanent magnetization (NRM) and the susceptibility, from which the induced magnetization may be derived. Mean NRM intensities, together with additional basic magnetic properties, for guyots drilled during Leg 144 are summarized in Table 6. Although the number of analyses for some sites is small, the mean NRM intensities for all guyots are remarkably similar, despite differences in age and geochemistry among the various sites. This similarity suggests that it may be reasonable to combine data from all 
Table 4. Representative analyses of alteration phases.

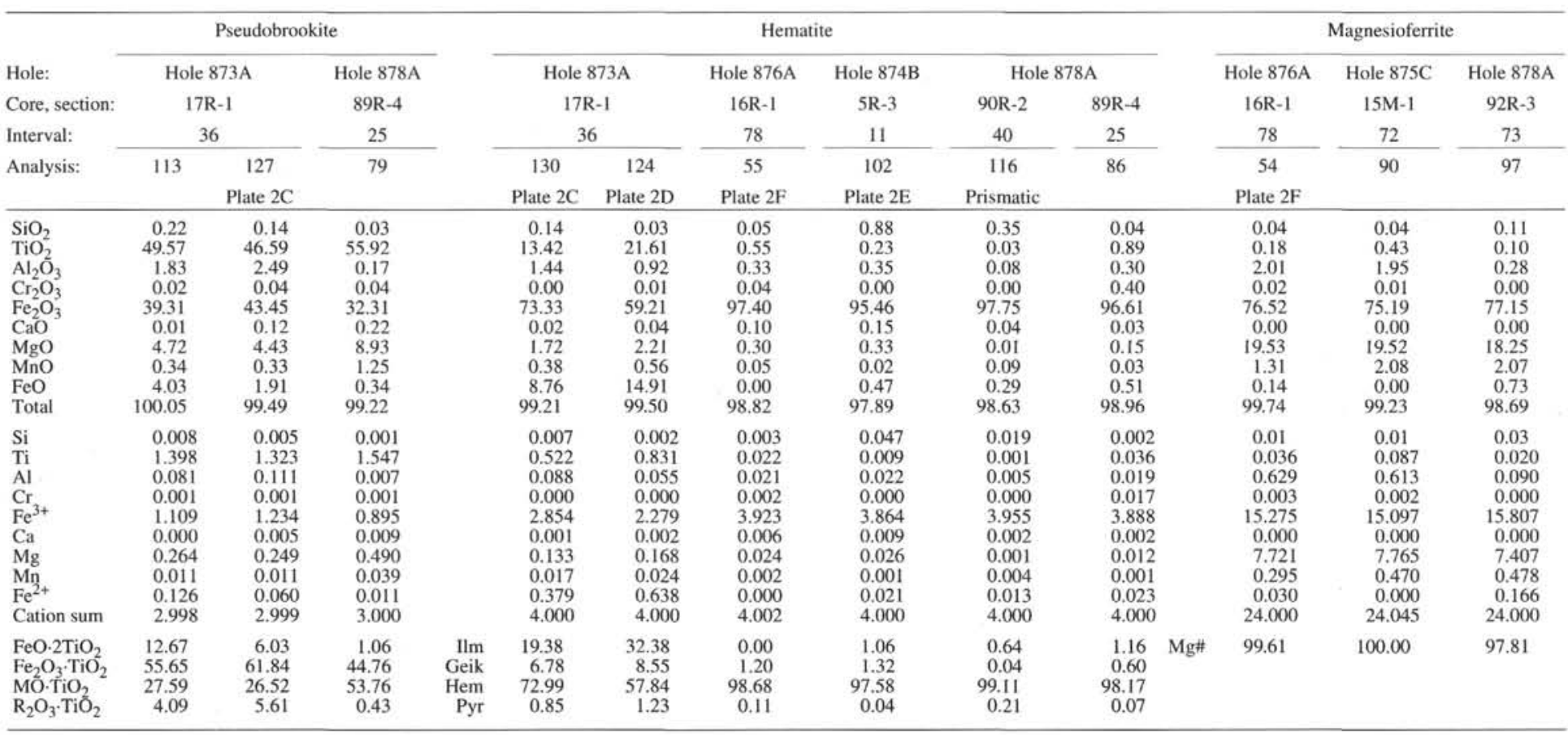

Notes: Pseudobrookite components after Bowles (1988). Analysis 79 is an armalcolite by this classification. Analysis spots shown in Plates 1 and 2 where noted. Mg\# as in Table 1. 
Table 5. Representative ilmenite compositions.

\begin{tabular}{|c|c|c|c|c|c|c|c|c|c|c|c|c|c|c|}
\hline \multirow{3}{*}{$\begin{array}{l}\text { Hole: } \\
\text { Core, section: } \\
\text { Interval: } \\
\text { Analysis: }\end{array}$} & \multirow{3}{*}{$\begin{array}{c}\frac{\text { Hole } 871 \mathrm{C}}{35 \mathrm{R}-1} \\
32 \\
20 \\
\text { In CPX }\end{array}$} & \multicolumn{3}{|c|}{ Hole 872 B } & \multirow{3}{*}{$\begin{array}{c}\text { Hole } 872 \mathrm{C} \\
\begin{array}{c}18 \mathrm{X}-1 \\
95\end{array} \\
88 \\
\begin{array}{c}\text { Ground. } \\
\text { lath }\end{array}\end{array}$} & \multirow{3}{*}{$\begin{array}{c}\text { Hole 873A } \\
17 \mathrm{R}-1 \\
50 \\
135 \\
\text { Plate 2A }\end{array}$} & \multirow{3}{*}{$\begin{array}{c}\frac{\text { Hole } 874 \mathrm{~B}}{24 \mathrm{R}-4} \\
42 \\
61 \\
\text { Plate IE }\end{array}$} & \multicolumn{7}{|c|}{ Hole878A } \\
\hline & & $\begin{array}{c}8 \mathrm{R}-2 \\
139\end{array}$ & $\begin{array}{c}\text { 7R-7 } \\
54\end{array}$ & $\begin{array}{c}5 \mathrm{R}-3 \\
11\end{array}$ & & & & \multirow{2}{*}{$\begin{array}{c}\begin{array}{c}81 \mathrm{R}-3 \\
30\end{array} \\
\begin{array}{c}61 \\
\text { Sandwich } \\
\text { lamellae }\end{array}\end{array}$} & \multirow{2}{*}{$\begin{array}{c}84 R-4 \\
47 \\
118 \\
\text { Ground. } \\
\text { lath }\end{array}$} & \multirow{2}{*}{$\begin{array}{c}\begin{array}{c}86 \mathrm{R}-3 \\
39\end{array} \\
30 \\
\text { In olivine }\end{array}$} & \multirow{2}{*}{$\begin{array}{c}\begin{array}{c}91 \mathrm{R}-3 \\
86\end{array} \\
77 \\
\text { Plate 1E }\end{array}$} & \multirow{2}{*}{$\begin{array}{c}98 \mathrm{R}-3 \\
88 \\
\begin{array}{c}152 \\
\text { Ground. } \\
\text { lath }\end{array}\end{array}$} & \multicolumn{2}{|c|}{$\begin{array}{c}83 R-4 \\
11\end{array}$} \\
\hline & & $\begin{array}{c}54 \\
\text { Intergrown } \\
53 \text { (Tb.3) }\end{array}$ & 32 & $\begin{array}{c}101 \\
\text { Plate 2E }\end{array}$ & & & & & & & & & $\begin{array}{c}100 \\
\text { Intergrown } \\
101 \text { (Tb.3) }\end{array}$ & $\begin{array}{c}107 \\
\text { In olivine }\end{array}$ \\
\hline $\mathrm{SiO}_{2}$ & 0.01 & 0.16 & 0.07 & 0.21 & 0.00 & 0.14 & 0.09 & 0.09 & 0.06 & 0.00 & 0.04 & 0.03 & 0.12 & 0.04 \\
\hline $\mathrm{TiO}_{2}^{2}$ & 49.70 & 47.63 & 49.81 & 27.19 & 50.95 & 48.81 & 49.41 & 49.34 & 52.05 & 47.13 & 47.65 & 51.36 & 50.03 & 50.50 \\
\hline $\mathrm{Al}_{2} \mathrm{O}_{3}$ & 0.26 & 0.16 & 0.04 & 0.44 & 0.03 & 0.19 & 0.11 & 0.91 & 0.05 & 0.61 & 0.12 & 0.08 & 0.18 & 0.03 \\
\hline $\mathrm{Cr}_{2} \mathrm{O}_{3}$ & 0.05 & 0.00 & 0.00 & 0.03 & 0.01 & 0.01 & 0.00 & 0.77 & 0.04 & 0.37 & 0.12 & 0.07 & 0.15 & 0.02 \\
\hline $\mathrm{Fe}_{2} \mathrm{O}_{3}$ & 10.85 & 12.24 & 4.51 & 44.72 & 2.40 & 10.65 & 5.07 & 8.10 & 3.33 & 14.94 & 10.56 & 4.87 & 4.87 & 4.05 \\
\hline $\mathrm{CaO}$ & 0.38 & 0.15 & 0.11 & 0.14 & 0.04 & 0.03 & 0.28 & 0.14 & 0.47 & 0.01 & 0.05 & 0.18 & 0.13 & 0.06 \\
\hline $\mathrm{MgO}$ & 7.16 & 5.92 & 1.31 & 0.91 & 0.33 & 5.79 & 1.64 & 5.01 & 2.81 & 6.84 & 3.15 & 3.67 & 2.45 & 2.88 \\
\hline $\mathrm{MnO}$ & 0.41 & 0.62 & 0.95 & 0.43 & 1.43 & 10.48 & 0.83 & 1.14 & 0.81 & 0.32 & 0.5 & 0.54 & 25.01 & 21.04 \\
\hline $\mathrm{FeO}$ & 31.04 & 31.65 & 41.43 & 22.47 & 43.75 & 23.09 & 40.42 & 34.22 & 40.44 & 29.86 & 36.72 & 38.91 & 15.28 & 18.95 \\
\hline Total & 99.85 & 98.54 & 98.22 & 96.55 & 98.94 & 99.19 & 97.86 & 99.71 & 100.06 & 100.08 & 98.91 & 99.71 & 98.21 & 97.57 \\
\hline $\mathrm{Si}$ & & & 0.003 & 0.011 & 0.000 & 0.007 & 0.005 & 0.004 & 0.003 & 0.000 & 0.002 & 0.002 & 0.006 & 0.002 \\
\hline Ti & & 1.76 & & & & & & & 1.93 & & & & & 1.919 \\
\hline $\mathrm{Al}$ & 0.015 & 0.009 & 0.002 & 0.02 & 0.0 & 0.0 & 0.0 & 0.05 & 0.00 & 0.0 & 0.0 & 0.005 & 0.010 & 0.002 \\
\hline $\mathrm{Cr}_{2}$ & 0.002 & 0.000 & 0.000 & 0.06 & & 0.0 & 0.0 & 0.03 & 0.0 & 0.0 & 0.0 & 0.003 & 0.006 & 0.001 \\
\hline $\mathrm{Fe}^{3+}$ & 0.392 & 0.45 & 0.173 & 1.78 & 0.0 & 0.39 & 0.1 & 0.29 & 0.12 & 0.5 & 0.3 & 0.181 & 0.185 & 0.154 \\
\hline $\mathrm{Ca}$ & 0.019 & 0.00 & 0.006 & 0.00 & 0.0 & 0.0 & 0.0 & 0.00 & 0.0 & 0.0 & 0.0 & 0.009 & 0.007 & 0.003 \\
\hline $\mathrm{Mg}$ & 0.513 & 0.434 & 0.100 & 0.07 & 0.0 & 0.421 & 0.12 & 0.3 & 0.2 & 0.4 & 0.2 & 0.270 & 0.183 & 0.217 \\
\hline $\mathrm{Mn}$ & 0.017 & 0.026 & 0.041 & 0.019 & 0.062 & 0.433 & 0.036 & 0.047 & 0.03 & 0.013 & 0.0 & 0.022 & 1.066 & 0.901 \\
\hline $\mathrm{Fe}^{2+}$ & 1.247 & 1.301 & 1.766 & 0.995 & 1.865 & 0.943 & 1.724 & 1.393 & 1.670 & 1.201 & 1.537 & 1.604 & 0.643 & 0.801 \\
\hline Cation sum & 4.000 & 4.000 & 4.000 & 4.000 & 4.000 & 4.000 & 4.000 & 4.000 & 4.000 & 4.000 & 4.000 & 4.000 & 4.000 & 4.000 \\
\hline Ilm. & 63.21 & 65.48 & 88.59 & 50.34 & 93.37 & 47.31 & 86.99 & 71.38 & 84.65 & 60.82 & 77.16 & 80.74 & 32.40 & 40.15 \\
\hline Geik. & 26.00 & 21.8 & 5.01 & 3.6 & 1.2 & 21.1 & 6.3 & 18.6 & 10.5 & 24. & 11. & 13.59 & 9.24 & 10.86 \\
\hline Hem. & 9.95 & 11.39 & 4.34 & 45.07 & 2.31 & 9.82 & 4.9 & 7.61 & 3.1 & 13.69 & 9.9 & 4.54 & 4.65 & 3.86 \\
\hline Pyr. & 0.85 & 1.29 & 2.06 & 0.98 & 3.09 & 21.74 & 1.80 & 2.41 & 1.71 & 0.65 & 1.07 & 1.13 & 53.71 & 45.13 \\
\hline
\end{tabular}

Notes: Analysis spots shown in Plates 1 or 2 where noted. Ground. lath = lath-shaped grain in groundmass. 
Table 6. Summary of magnetic data for Leg 144 guyots.

\begin{tabular}{|c|c|c|c|c|c|c|c|c|}
\hline Site & Guyot & $\begin{array}{c}\text { Number of } \\
\text { samples }\end{array}$ & & $\begin{array}{l}\mathrm{NRM} \\
(\mathrm{A} / \mathrm{m})\end{array}$ & $\begin{array}{c}\text { Koenigsberger } \\
\text { ratio }(\mathrm{Q})\end{array}$ & $\begin{array}{l}\text { MDF } \\
(\mathrm{mT})\end{array}$ & $\begin{array}{l}\text { Number of } \\
\text { flow units } \\
\text { (samples) }\end{array}$ & Inclination \\
\hline 871 & Limalok & $46(34)$ & $\begin{array}{l}\text { A.M. } \\
\text { G.M. }\end{array}$ & $\begin{array}{l}3.54( \pm 3.4) \\
2.72( \pm 0.30)\end{array}$ & $\begin{array}{l}4.78( \pm 4.5) \\
3.63( \pm 0.33)\end{array}$ & $\begin{array}{c}17.6( \pm 10.4) \\
N=17\end{array}$ & $12(44)$ & -19.1 \\
\hline 872 & Lo-En & $47(38)$ & $\begin{array}{l}\text { A.M. } \\
\text { G.M. }\end{array}$ & $\begin{array}{l}3.78( \pm 2.7) \\
2.72( \pm 0.43)\end{array}$ & $\begin{array}{l}10.5( \pm 4.9) \\
9.27( \pm 0.24)\end{array}$ & $\begin{array}{c}30.2( \pm 23.6) \\
N=23\end{array}$ & $11(44)$ & -49.8 \\
\hline $873-877$ & Wodejebato & $45(42)$ & $\begin{array}{l}\text { A.M. } \\
\text { G.M. }\end{array}$ & $\begin{array}{l}4.56( \pm 0.51) \\
3.23( \pm 0.38)\end{array}$ & $\begin{array}{l}17.8( \pm 17.3) \\
11.0( \pm 0.46)\end{array}$ & $\begin{array}{c}24.6( \pm 13.8) \\
N=30\end{array}$ & $11(40)$ & 16.5 \\
\hline 878 & MIT & 106 & $\begin{array}{l}\text { A.M. } \\
\text { G.M. }\end{array}$ & $\begin{array}{l}3.20( \pm 2.8) \\
1.98( \pm 0.47)\end{array}$ & $\begin{array}{l}5.76( \pm 5.9) \\
3.21( \pm 0.52)\end{array}$ & $\begin{array}{c}30.4( \pm 21.6) \\
N=63\end{array}$ & $23(83)$ & $22.1 *$ \\
\hline \multirow[t]{2}{*}{879} & Takuyo-Daisan & 14 & $\begin{array}{l}\text { A.M. } \\
\text { G.M. }\end{array}$ & $\begin{array}{l}3.44( \pm 2.5) \\
2.30( \pm 0.52)\end{array}$ & $\begin{array}{l}28.7( \pm 21.3) \\
18.6( \pm 0.52)\end{array}$ & $\begin{array}{c}31.6( \pm 15.3) \\
N=9\end{array}$ & $1(14)$ & -19.2 \\
\hline & All sites & 266 & $\begin{array}{l}\text { A.M. } \\
\text { G.M. }\end{array}$ & $\begin{array}{l}3.53( \pm 3.2) \\
2.34( \pm 0.44)\end{array}$ & $\begin{array}{l}9.78( \pm 11.9) \\
5.34( \pm 0.51)\end{array}$ & $\begin{array}{c}27.6( \pm 19.3) \\
N=144\end{array}$ & & \\
\hline
\end{tabular}

Notes: Number of samples in parentheses is for Q. A.M. = arithmetic mean; \pm 1 standard deviation. G.M. $=$ geometric mean; \pm 1 standard deviation expressed in log units. Single asterisk $(*)=$ mean inclination based on mean of 10 normal polarity and 13 reversed polarity flows, excluding 3 transitional flows.

sites to obtain the best estimate of the remanent intensity for these western Pacific guyots. The combined distribution of NRM intensities (Fig. 4) is approximately lognormal, as has been previously noted by various authors (e.g., Kono, 1980; Gee et al., 1989). The overall mean NRM $(3.53 \pm 3.2 \mathrm{~A} / \mathrm{m}$, arithmetic mean; $2.34 \pm 0.44 \log$ units, geometric mean) is similar to most previously reported values from drilled (Marshall, 1978; Kono, 1980; Rice et al., 1980) and dredged (Furuta et al., 1980; Gee et al., 1988) material from seamounts and guyots. It is interesting to note that dredged samples from very young seamounts (e.g., Axial Seamount, Loihi Seamount) have NRM intensities significantly higher than that of samples from Leg 144 guyots. Although the number of seamounts with adequate sampling is small, the much higher intensity for the essentially zero-age samples from the Axial (38 $\mathrm{A} / \mathrm{m}$; Tivey and Johnson, 1990) and Loihi ( 20 A/m; Johnson and Clague, 1981) seamounts suggests a time-dependent decay of the magnetization of seamount rocks. The magnitude of this presumed intensity reduction (approximately an order of magnitude) is similar to that documented for samples from the oceanic crust (e.g., Irving, 1970; Johnson and Atwater, 1977), although the time constant for the magnetization decay is uncertain.

The magnetic anomaly associated with seamounts arises from the combined remanent and induced magnetization of the source rocks. The Königsberger ratio $(Q)$ provides an indication of the relative contribution of the two magnetizations and, hence, gives a limit on the potential bias in seamount paleopoles that may be introduced by induced magnetization. The Königsberger ratio for samples from Leg 144 was calculated using the IGRF value at each site (ranging from $0.034 \mathrm{mT}$ at Site $871\left[5.5^{\circ} \mathrm{N}\right]$ to $0.044 \mathrm{mT}$ at Site $\left.879\left[34.1^{\circ} \mathrm{N}\right]\right)$. As noted for NRM intensities, the distribution of Königsberger ratios (Fig. 4B) is roughly lognormal, although the distribution is slightly skewed toward lower values. The mean values of $Q$ for the various guyots (Table 6) range from a low of 4.78 for Limalok Guyot to a high of 28.7 for Takuyo-Daisan Guyot. The latter value reflects the lower average susceptibility in the fine-grained amoeboidal lavas from this site, although the small number of samples (from a single flow unit) may not be representative for the bulk of the seamount edifice. The arithmetic mean value of $Q$ for the combined data set (9.78) implies an induced magnetization contribution of approximately $10 \%$ of the total seamount magnetization.

\section{Magnetic Stability}

A fundamental assumption inherent in seamount anomaly modeling is that the remanent magnetization preserves an accurate record of the time-averaged geomagnetic field during seamount construction. Some estimate of the stability of the remanence is useful, therefore, in evaluating the validity of this assumption. Although the coercivity of remanence $\left(H_{\mathrm{rc}}\right)$ or bulk coercivity $\left(H_{\mathrm{c}}\right)$ might constitute a more suit- able indicator of the remanent stability, the median destructive field (MDF; the alternating field necessary to reduce the magnetization to half its original value) provides a first-order estimate of the magnetic stability. The MDFs for samples from Leg 144 range from $\sim 2 \mathrm{mT}$ to values above the peak field $(100 \mathrm{mT})$ attainable with the AF demagnetizers used in this study (Fig. 5). The mean value for the distribution is $\sim 28 \mathrm{mT}$, suggesting a reasonably stable remanence.

The presence or absence of low-stability magnetic overprints provides an additional indication of the magnetic stability. The majority of samples from guyots drilled during Leg 144 have nearly univectorial demagnetization behavior or exhibit only moderate low-stability secondary magnetization components (Premoli Silva, Haggerty, Rack, et al., 1993). Significant low-stability overprints are prevalent only in the reversed polarity samples from the lower portion of Hole 878A. Although one might expect a higher proportion of samples with significant low-stability overprints, given the age and potentially complex remanence history of these samples, the dominance of singlecomponent magnetizations is generally compatible with the moderate stability inferred from the MDFs. The Northern Hemisphere present location and negative inclinations (Southern Hemisphere normal polarity) for samples from Limalok, Lo-En and Takuyo-Daisan guyots effectively rule out a recent viscous origin for these remanence directions (Table 6). A similar argument holds for samples from the lower portion of Hole 878A (MIT Guyot), which have positive characteristic inclinations but often significant low-stability, negative inclination overprints.

\section{Curie Temperatures}

Curie temperatures were determined for approximately 65 samples to provide additional information on the magnetic mineralogy and alteration history of the Leg 144 sample collection. Although there is substantial variability, the majority of high field magnetization curves can be classified into one of four categories (Fig. 6). Curie temperature data of samples examined petrographically (or immediately adjacent samples) are summarized in Table 1. Type I curves are characterized by a low initial Curie point (typically $200^{\circ}-300^{\circ} \mathrm{C}$ ), a magnetization increase at temperatures of $\sim 350^{\circ}-400^{\circ} \mathrm{C}$, and irreversibility in which the final room temperature magnetization is significantly higher than the initial magnetization. This type of curve is characteristic of cation-deficient titanomaghemites (e.g., Ozima and Ozima, 1971), suggesting the dominance of low-temperature oxidation. The second type of Curie temperature curve (Type II) has a single high-temperature Curie point, with reversible or nearly reversible behavior upon cooling. The high initial Curie temperature (typically $\sim 575^{\circ} \mathrm{C}$ ) is compatible with the presence of nearly pure magnetite. Type III curves show evidence of two Curie points (generally $\sim 300^{\circ} \mathrm{C}$ and $>500^{\circ} \mathrm{C}$ ), which are clearly delineated, in some cases, by 


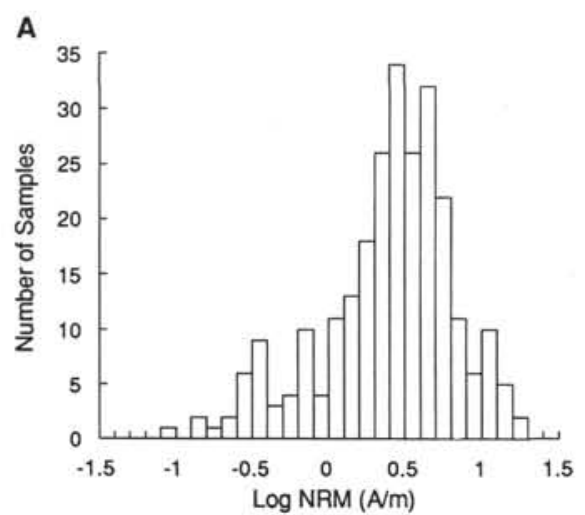

B

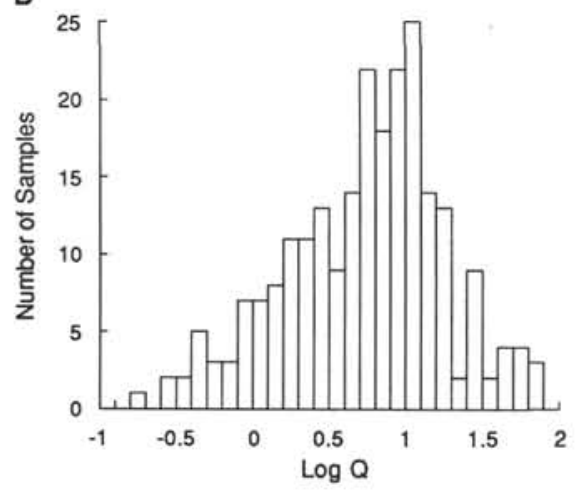

Figure 4. Histograms of (A) the log of the NRM intensity and (B) the log of the Königsberger ratio $(Q)$ for samples from Leg 144.

an intervening magnetization plateau. In other instances, magnetization increases slightly at approximately $350^{\circ}-400^{\circ} \mathrm{C}$, reminiscent of the irreversible behavior in Type I curves (Fig. 6C). The presence of a noticeable inflection point near $500^{\circ} \mathrm{C}$, together with the lower magnetization upon cooling, suggests that this type of behavior may represent a mixture of an oxidized titanomaghemite and an initial high Curie point phase. For Type III curves, the dominant Curie point is listed in Table 1, with the subordinate Curie temperature in parentheses. Finally, the fourth type of curve (Type IV) is characterized by irreversible behavior, with the final magnetization generally lower than the initial room temperature value, and a distinctive kink in the heating curve at a temperature between $120^{\circ} \mathrm{C}$ and $200^{\circ} \mathrm{C}$. These curves generally have an inflection (temperature in parentheses in Table 1) at approximately $400^{\circ} \mathrm{C}$ and have high initial Curie temperatures $\left(550^{\circ}\right.$ to $\left.>600^{\circ} \mathrm{C}\right)$. This type of high field magnetization curve has been associated with hydrothermal alteration (Ade-Hall et al., 1971) although the mechanism responsible for the distinctive kink in the heating curve remains uncertain.

These various types of Curie temperature curves, and the presumed mineralogical or alteration features associated with each type, correlate reasonably well with the dominant type and degree of alteration determined petrographically (Table 1). For example, samples from Site 871 have almost exclusively Type I curves with initial Curie temperatures ranging from $220^{\circ}$ to $300^{\circ} \mathrm{C}$, consistent with the dominance of lowtemperature alteration inferred from petrographic observations. Likewise, the variability in alteration within the ankaramitic flow(s) from Hole $874 \mathrm{~B}$ is paralleled by changes in Curie temperature behavior. The most highly oxidized sample (Sample 144-874B-23R-1, 32-34 cm) has a Type IV curve with an initial Curie temperature of $\sim 630^{\circ} \mathrm{C}$. The sample from an intermediate level within this large flow unit has evidence for both high- and low-temperature oxidation and a corresponding Type III Curie temperature curve (Curie points of $300^{\circ} \mathrm{C}$ and $560^{\circ} \mathrm{C}$ ). The lowermost sample from this flow (Sample 144-874B-

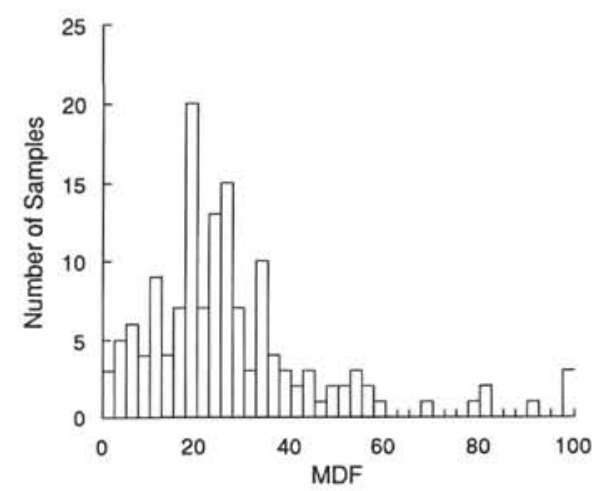

Figure 5. Histogram of the MDF for samples from Leg 144. The MDF is the alternating field $(\mathrm{mT})$ required to reduce the remanence to half its original value.

$24 \mathrm{R}-4,42-44 \mathrm{~cm}$ ) exhibits no evidence of high-temperature oxidation and has a Type I Curie temperature curve with an initial Curie point of $\sim 250^{\circ} \mathrm{C}$. The remanent inclination $\left(20.9^{\circ}\right)$ of samples from the lower part of this flow is distinct from that of the upper portion $\left(10.0^{\circ}\right)$, possibly indicating the presence of an unrecognized flow boundary within this unit.

A comparison of high field magnetizations, petrographic observations, and unblocking temperature spectra from samples from Sites 875 and 876 on the perimeter of Wodejebato guyot suggests that magnesioferrite and hematite may, at least locally, be the dominant remanence carriers (Fig. 7). Four of the five samples examined from Sites 875 and 876 have an oxide assemblage that includes magnesioferrite and hematite, locally to the apparent exclusion of titanomagnetite grains. Thermal demagnetization of one of these samples (144$875 \mathrm{C}-15 \mathrm{M}-1,72-74 \mathrm{~cm}$; Fig. 7A) reveals substantial unblocking in the temperature range from $300^{\circ}$ to $350^{\circ} \mathrm{C}$, coincident with the Curie temperature of stoichiometric magnesioferrite (e.g., O'Neill et al., 1992). The remaining remanence has maximum unblocking temperatures of $625^{\circ} \mathrm{C}$, suggesting a significant contribution from hematite. The Curie temperature curve for a second sample (from Hole 876A) shows two well-defined Curie points (at $\sim 300^{\circ} \mathrm{C}$ and $625^{\circ} \mathrm{C}$ ) and nearly reversible behavior upon cooling (Fig. 7B). The coincidence of the blocking temperature data and the Curie temperatures suggests that magnesioferrite and hematite may be entirely responsible for the remanent magnetization of this sample. The NRM intensities of similarly altered samples from Sites 875 and $876(1-5 \mathrm{~A} / \mathrm{m})$ are similar to values for the remaining samples from Wodejebato Guyot. We note that these sites on the margin of the guyot include several samples with shallow directions and some negative inclinations (Figs. 7C-7D), in contrast to the dominant positive inclinations (Southern Hemisphere reversed polarity) for the guyot. Because petrographic observations indicate that the highly oxidized magnesioferrite + hematite assemblage is concentrated along vesicle margins and in brecciated flow tops, it is possible that the localized migration of fluids may have resulted in remagnetization (normal polarity) of portions of the section sampled at Sites $875-877$ significantly after the emplacement of these flows. Unfortunately, the small size of many of these core pieces and the high percentage of samples accidentally inverted during sampling or curation (see Nakanishi and Gee, this volume) preclude any definitive resolution of this issue.

\section{DISCUSSION}

Oxide minerals in samples from western Pacific guyots drilled during Leg 144 span a wide compositional range and have experienced alteration under diverse conditions, ranging from low-temperature oxidation to the higher temperature and highly oxidizing conditions recorded by coexisting magnesioferrite and hematite (Johnston and Stout, 1984). Perhaps the most important aspect of the oxide min- 

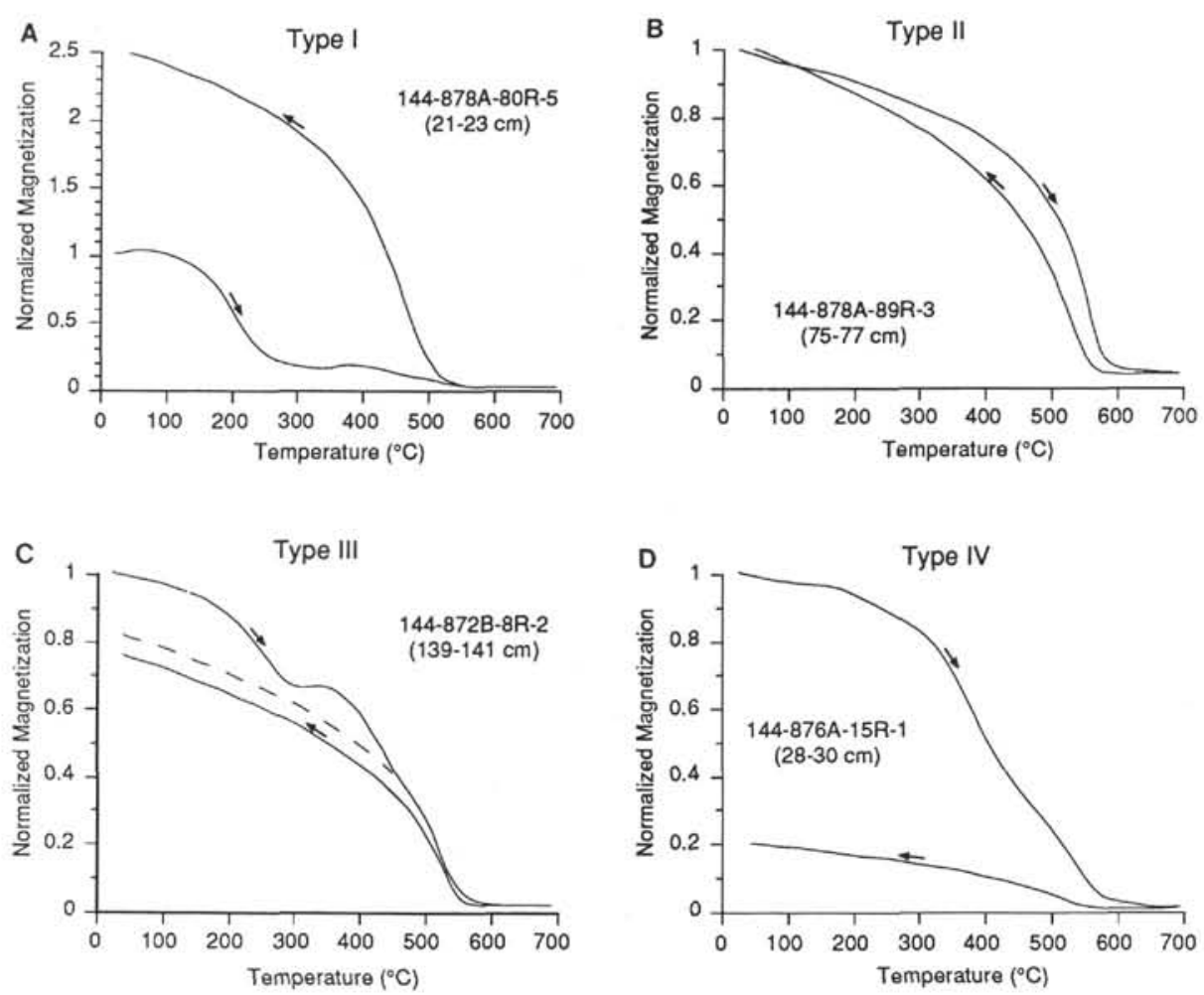

Figure 6. Representative Curie temperature curves for samples from Leg 144. The magnetization value is normalized to the initial room temperature value. See text for discussion of the four types of curves.

eralogical data is the compositional range and abundance of minor elements in the titanomagnetites. Although no simple correlation exists between ulvöspinel content and rock type, the titanomagnetites in these alkalic lavas span much of the magnetite-ulvöspinel solid-solution series. The initial Curie temperatures of stoichiometric titanomagnetites with ulvöspinel contents greater than $x=0.75\left(\mathrm{Tc}=\sim 30^{\circ} \mathrm{C}\right)$ would make the samples paramagnetic under ambient conditions. The addition of aluminum, magnesium, and chromium results in even lower Curie temperatures (e.g., O'Reilly, 1984; Özdemir and Moskowitz, 1992). As noted previously by Smith et al. (1991), the low inferred Curie temperatures for many of these titanomagnetites suggest that much of the remanence may be a chemical remanence acquired as the Curie temperature is elevated during low-temperature oxidation. The modified ulvöspinel content $\left(x^{\prime}\right)$ should provide a reasonable estimate of the initial Curie temperature for samples in which $\mathrm{Al}+\mathrm{Cr}>\mathrm{Mg}+$ $\mathrm{Mn}$ (e.g., Site 871). The predicted Curie temperatures $\left(<75^{\circ} \mathrm{C}\right)$ and the dominance of low-temperature alteration for samples from Site 871 suggest that a significant fraction of the remanence in these lavas may have been acquired during alteration.

Guyots drilled during Leg 144 have substantially increased the amount of available material for assessing the magnetic properties of seamount lithologies, and hence the potential bias in paleopoles derived from seamount magnetic anomaly data. Although these samples represent only the outermost portion of the volcanic edifice, the mean intensity $(3.53 \mathrm{~A} / \mathrm{m})$ and $\mathrm{Q}$ ratio $(9.8)$ are similar to results from seamount rocks sampled by dredging and drilling and in subaerial seamount exposures (Marshall, 1978; Kono, 1980; Gee et al., 1988, 1989; Smith et al., 1991). The average Q ratio of extrusive samples from Leg 144 implies an approximate $10 \%$ contribution from induced magnetization. This value is compatible with the $15 \%-25 \%$ combined contribution from viscous and induced magnetization suggested by studies of the subaerially exposed La Palma Seamount Series (Gee et al., 1993) and estimates derived from analysis of seamount magnetic anomaly data (Hildebrand and Staudigel, 1986; Bryan and Gordon, 1991).
The potential bias in seamount paleopoles arising from viscous and induced magnetization is a function of the paleolatitude and polarity of the seamount, as well as the amount of latitudinal displacement since seamount formation (Gee et al., 1993). The low southerly paleolatitudes and large (up to $40^{\circ}$ ) northward translations of Cretaceous guyots in the western Pacific suggest that significant errors might be present in the paleopoles for these seamounts. Indeed, the observed inclinations for Lo-En, MIT, and Takuyo-Daisan guyots (Table 6) differ from those inferred from the magnetic anomaly data in the sense expected from a viscous or induced magnetization contribution. The normal-polarity Southern Hemisphere inclination of Lo-En $\left(-49.8^{\circ}\right)$ and Takuyo-Daisan $\left(-19.2^{\circ}\right)$ guyots are significantly more negative than the average model inclinations (Lo-En, $-26.5^{\circ}$, Bryan et al., 1993; Takuyo-Daisan, $4.9^{\circ}$, Sager et al., 1993), although the discrepancy for Takuyo-Daisan may be somewhat reduced after correction for the $\sim 10^{\circ}$ deviation of Hole 879A from vertical (Premoli Silva, Haggerty, Rack, et al., 1993). Similarly, the inclination $\left(22^{\circ}\right)$ of reversed polarity lavas at MIT Guyot is shallower than the $52.2^{\circ}$ inclination derived from the sea-surface anomaly data (Sager et al., 1993). Although these results are compatible with a significant induced and/or viscous magnetization contribution, substantial viscous overprints are not prevalent in most of the shallow lavas sampled during Leg 144. Viscous and induced magnetizations may, however, be preferentially associated with intrusive rocks at deeper levels (e.g., Smith, 1984; Gee et al., 1989, 1993).

\section{ACKNOWLEDGMENTS}

We are indebted to G.M. Smith and S.E. Haggerty for providing thoughtful reviews of the manuscript. Special thanks are extended to D.V. Kent for many helpful discussions, to G. Mello for help in measuring the samples, and to L. Norby for help during the microprobe work which forms the basis of this study. This work was in part supported by a USSAC grant to J. Gee. Lamont-Doherty Earth Observatory Contribution No. 5433. 

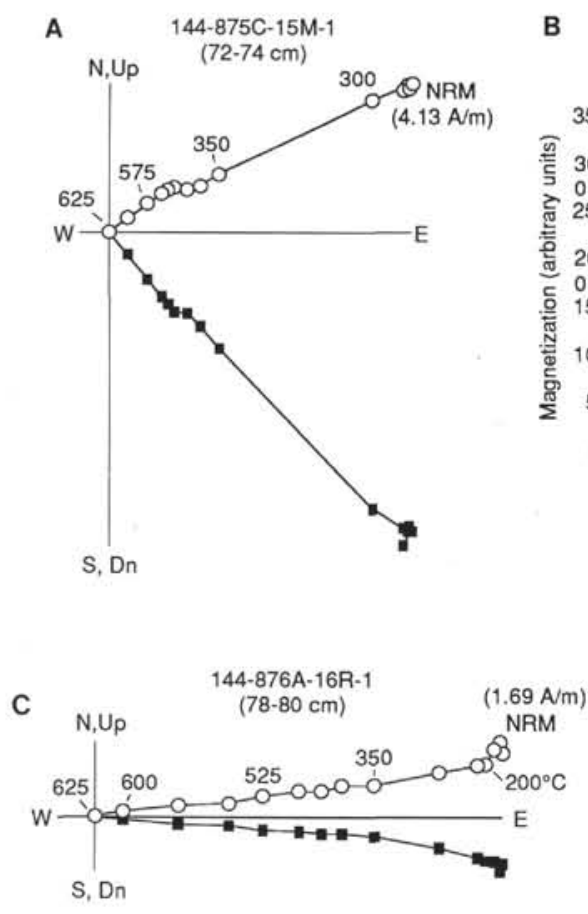

B
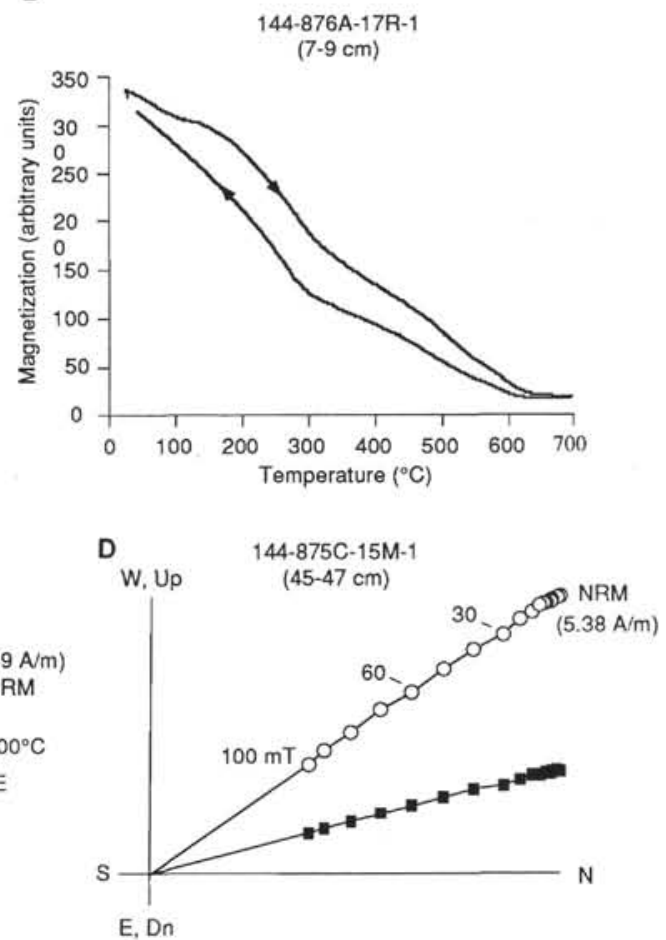

Figure 7. Vector endpoint demagnetization diagrams (Figs. 1A, 1C, and 1D) and Curie temperature curve (Fig. 1B) for samples from Wodejebato Guyot illustrating the potential contribution of magnesioferrite and hematite to the remanence. A. Thermal demagnetization of sample with peak unblocking temperatures consistent with a remanence carried by magnesioferrite and hematite. Note that this sample is from a short core piece and therefore may not be vertically oriented. B. Curie temperature curve illustrating probable contribution from magnesioferrite and hematite. C. Thermal demagnetization of sample from Hole 876A illustrating high blocking temperature and shallow negative inclination. D. Alternating field demagnetization of sample from Hole $875 \mathrm{C}$ with negative inclination. Filled squares (open circles) in Figures 1A, 1C, and 1D are projections of the magnetization vector onto the horizontal (vertical) plane. NRM intensities are given in parentheses.

\section{REFERENCES*}

Ade-Hall, J.M., Palmer, H.C., and Hubbard, T.P., 1971. The magnetic and opaque petrological response of basalts to regional hydrothermal alteration. Geophys. J. R. Astron. Soc., 24:137-174.

Allan, J.F., Sack, R.O., and Batiza, R., 1988. Cr-rich spinels as petrogenetic indicators: MORB-type lavas from the Lamont Seamount Chain, eastern Pacific. Am. Mineral., 73:741-753.

Bacon, C.R., and Hirschmann, M.M., 1988. Mg/Mn partitioning as a test for equilibrium between coexisting Fe-Ti oxides. Am. Mineral., 73:57-61.

Bowles, J.F.W., 1988. Definition and range of composition of naturally occurring minerals with the pseudobrookite structure. Am. Mineral., 73:1377-1383.

Bryan, P., and Gordon, R.G., 1991. Determining the average contribution of viscous overprints to the characteristic magnetization of Pacific seamounts. Eos, 72:125. (Abstract)

Bryan, P.C., Shoberg, T., Gordon, R.G., Petronotis, K.E., and Bergersen, D.D., 1993. A paleomagnetic pole and estimated age for Lo-En Guyot, Republic of the Marshall Islands. In Pringle, M.S., Sager, W.W., Sliter, W.V., and Stein, S. (Eds.), The Mesozoic Pacific: Geology, Tectonics, and Volcanism. Geophys. Monogr., Am. Geophys. Union, 77:387-400.

Cawthorn, R.G., and Biggar, G.M., 1993. Crystallization of titaniferous chromite, magnesian ilmenite and armalcolite in tholeitic suites in the Karoo Igneous Province. Contrib. Mineral. Petrol., 114:221-235.

Clague, D.A., Fisk, M.R., and Bence, A.E., 1980. Mineral chemistry of basalts from Ojin, Nintoku, and Suiko seamounts, Leg 55 DSDP. In Jackson, E.D., Koizumi, I., et al., Init. Repts. DSDP, 55: Washington (U.S. Govt. Printing Office), 607-637.

Ferguson, A.K., 1978. The occurrence of Ramsayite, Titan-lavenite and a fluorine-rich eucolite in a nepheline-syenite inclusion from Tenerife, $\mathrm{Ca}$ nary Islands. Contrib. Mineral. Petrol., 66:15-20.

\footnotetext{
"Abbreviations for names of organizations and publications in ODP reference lists follow the style given in Chemical Abstracts Service Source Index (published by American Chemical Society).
}

Francheteau, J., Harrison, C.G.A., Sclater, J.G., and Richards, M.L., 1970. Magnetization of Pacific seamounts: a preliminary polar wander curve for the northeastern Pacific. J. Geophys. Res., 75:2035-2061.

Frost, B.R., and Lindsley, D.H., 1991. Occurrence of iron-titanium oxides in igneous rocks. In Lindsley, D.H. (Ed.), Oxide Minerals: Petrologic and Magnetic Significance. Mineral. Soc. Am., Rev. Mineral., 25:433-468.

Furuta, T., Tonouchi, S., and Nakada, M., 1980. Magnetic properties of pillow basalt from the Kinan seamount chain, the Shikoku Basin. J. Geomagn. Geoelectr., 32:567-573.

Gee, J., Staudigel, H., and Tauxe, L., 1989. Contribution of induced magnetization to magnetization of seamounts. Nature, 342:170-173.

Gee, J., Staudigel, H., Tauxe, L., Pick, T., and Gallet, Y., 1993. Magnetization of the La Palma Seamount Series: implications for seamount paleopoles. J. Geophys. Res., 98:11743-11767.

Gee, J., Tauxe, L., Hildebrand, J.A., Staudigel, H., and Lonsdale, P., 1988. Nonuniform magnetization of Jasper Seamount. J. Geophys. Res., 93:12159-12,175.

Grommé, C.S., Wright, T.L., and Peck, D.L., 1969. Magnetic properties and oxidation of iron-titanium oxide minerals in Alae and Makaopuhi lava lakes, Hawaii. J. Geophys. Res. 74:5277-5293.

Haggerty, S.E., 1976. Oxidation of opaque mineral oxides in basalts. In Rumble, D., III (Ed.), Oxide Minerals. Mineral. Soc. Am., Rev. Mineral., $3: 101-140$.

1991. Oxide textures - a mini-atlas. In Lindsley, D.H. (Ed.), Oxide Minerals: Petrologic and Magnetic Significance. Mineral. Soc. Am., Rev. Mineral., 25:129-220.

Hildebrand, J.A., and Staudigel, H., 1986. Seamount magnetic polarity and Cretaceous volcanism of the Pacific Basin. Geology, 14:456-458.

Hurlbut, C.S., Jr., and Klein, C., 1977. Manual of Mineralogy: New York (Wiley).

Irving, E., 1970. The Mid-Atlantic Ridge at $45^{\circ} \mathrm{N}$. XIV. Oxidation and magnetic properties of basalt; review and discussion. Can. J. Earth Sci., 7:1528-1538.

Johnson, H.P., and Atwater, T., 1977. Magnetic study of basalts from the Mid-Atlantic Ridge, lat. $37^{\circ}$ N. Geol. Soc. Am. Bull., 88:637-647. 
Johnson, H.P., and Clague, D.A., 1981. Magnetic properties of submarine basalt as a function of rock geochemistry: samples from Loihi Seamount, Hawaii. Eos, 62:1082.

Johnson, H.P., and Hall, J.M., 1978. A detailed rock magnetic and opaque mineralogy study of the basalts from the Nazca Plate. Geophys. J. R. Astron. Soc., 52:45-64.

Johnston, A.D., and Stout, J.H., 1984. A highly oxidized ferrian salite-, kennedyite-, forsterite-, and rhönite-bearing alkali gabbro from Kauai, Hawaii, and its mantle xenoliths. Am. Mineral., 69:57-68.

Kemp, S.J., 1993. Mineralogical analysis of clays from the Ocean Drilling Program. Br. Geol. Surv., Mineral. and Petrol. Group Short Rep. MPSR/93/38.

Kono, M., 1980. Magnetic properties of DSDP Leg 55 basalts. In Jackson, E.D., Koisumi, I., et al., Init. Repts. DSDP, 55: Washington (U.S. Govt. Printing Office), 723-736.

Kyle, P.R., 1981. Mineralogy and geochemistry of a basanite to phonolite sequence at Hut Point Peninsula, Antarctica, based on core from Dry Valley Drilling Project drill holes 1, 2, and 3. J. Petrol., 22:451-500.

Marshall, M., 1978. The magnetic properties of some DSDP basalts from the North Pacific and inferences for Pacific plate tectonics. J. Geophys. Res., 83:289-308.

Merrill, R.T., and Burns, R.E., 1972. A detailed magnetic study of Cobb Seamount. Earth Planet. Sci. Lett., 14:413-418.

Nakanishi, M., Gee, J.S., and Scientific Party ODP Leg 144, 1992. Paleomagnetic studies of the northwestern Pacific guyots. Eos, 73:586 (Abstract).

O'Neill, H.S.C., Annersten, H., and Virgo, D., 1992. The temperature dependence of the cation distribution in magnesioferrite $\left(\mathrm{MgFe}_{2} \mathrm{O}_{4}\right)$ from powder XRD structural refinements and Mössbauer spectroscopy. Am. Mineral., 77:725-740.

O'Reilly, W., 1984. Rock and Mineral Magnetism: New York (Chapman and Hall).

Özdemir, Ö., and Moskowitz, B.M., 1992. Magnetostriction in aluminumsubstituted titanomagnetites. Geophys. Res. Lett., 19:2361-2364.

Ozima, M., Kaneoka, I., Saito, K., Honda, M., Yanagisawa, M., and Takigami, Y., 1983. Summary of geochronological studies of submarine rocks from the western Pacific Ocean. In Hilde, T.W.C., and Uyeda, S. (Eds.), Geodynamics of the Western Pacific-Indonesian Region. Am. Geophys. Union Geodyn. Ser., 11:137-142.

Ozima, M., and Ozima, M., 1971. Characteristic thermomagnetic curves in submarine basalts. J. Geophys. Res., 76:2051-2056.

Pariso, J.E., and Johnson, H.P., 1991. Alteration processes at Deep Sea Drilling Project/Ocean Drilling Program Hole 504B at the Costa Rica Rift: implications for magnetization of oceanic crust. J. Geophys. Res., 96:1170311722.
Perfit, M.R., and Fornari, D.J., 1983. Geochemical studies of abyssal lavas recovered by DSRV Alvin from eastern Galapagos Rift, Inca Transform, and Ecuador Rift, 2: phase chemistry and crystallization history. J. Geophys. Res., 88:10530-10550.

Premoli Silva, I., Haggerty, J., Rack, F., et al., 1993. Proc. ODP, Init. Repts., 144: College Station, TX (Ocean Drilling Program).

Ramdohr, P., 1969. The Ore Minerals and Their Intergrowths: New York (Pergamon),

Rice, P.D., Hall, J.M., and Opdyke, N.D., 1980. Deep Drill 1972: a paleomagnetic study of the Bermuda Seamount. Can. J. Earth Sci., 17:232-243.

Rumble, D.R., III, 1976. Oxide minerals in metamorphic rocks. In Rumble, D., III (Ed.), Oxide Minerals. Mineral. Soc. Am., Rev. Mineral., 3:89-113.

Sager, W.W., Duncan, R.A., and Handschumacher, D.W., 1993. Paleomagnetism of the Japanese and Marcus-Wake seamounts, western Pacific Ocean. In Pringle, M.S., Sager, W.W., Sliter, W.V., and Stein, S. (Eds.), The Mesozoic Pacific: Geology, Tectonics, and Volcanism. Geophys. Monogr., Am. Geophys. Union, 77:401-435.

Sigurdsson, H., and Schilling, J.-G., 1976. Spinels in Mid-Atlantic Ridge basalts: chemistry and occurrence. Earth Planet. Sci. Lett., 29:7-20.

Smith, B.M., 1984. Magnetic viscosity of some doleritic basalts in relation to the interpretation of the oceanic magnetic anomalies. Geophys. Res. Lett., 11:213-216.

Smith, G.M., Gee, J., and Klootwijk, C.T., 1991. Magnetic petrology of basalts from Ninetyeast Ridge. In Weissel, J., Peirce, J., Taylor, E., Alt, J., et al., Proc. ODP, Sci. Results, 121: College Station, TX (Ocean Drilling Program), 525-545.

Staudigel, H., and Schmincke, H.-U., 1984. The Pliocene Seamount Series of La Palma/Canary Islands. J. Geophys. Res., 89:11195-11215.

Stormer, J.C., Jr., 1983. The effects of recalculation on estimates of temperature and oxygen fugacity from analyses of multicomponent iron-titanium oxides. Am. Mineral., 68:586-594.

Thy, P., 1983. Spinel minerals in transitional and alkali basaltic glasses from Iceland. Contrib. Mineral. Petrol., 83:141-149.

Tivey, M.A., and Johnson, H.P., 1990. The magnetic structure of Axial Seamount, Juan de Fuca Ridge. J. Geophys. Res., 95:12735-12750.

Tompkins, L.A., and Haggerty, S.E., 1985. Groundmass oxide minerals in the Koidu kimberlite dikes, Sierra Leone, West Africa. Contrib. Mineral. Petrol., 91:245-263.

Date of initial receipt: 1 February 1994 Date of acceptance: 15 September 1994 Ms 144SR-020 

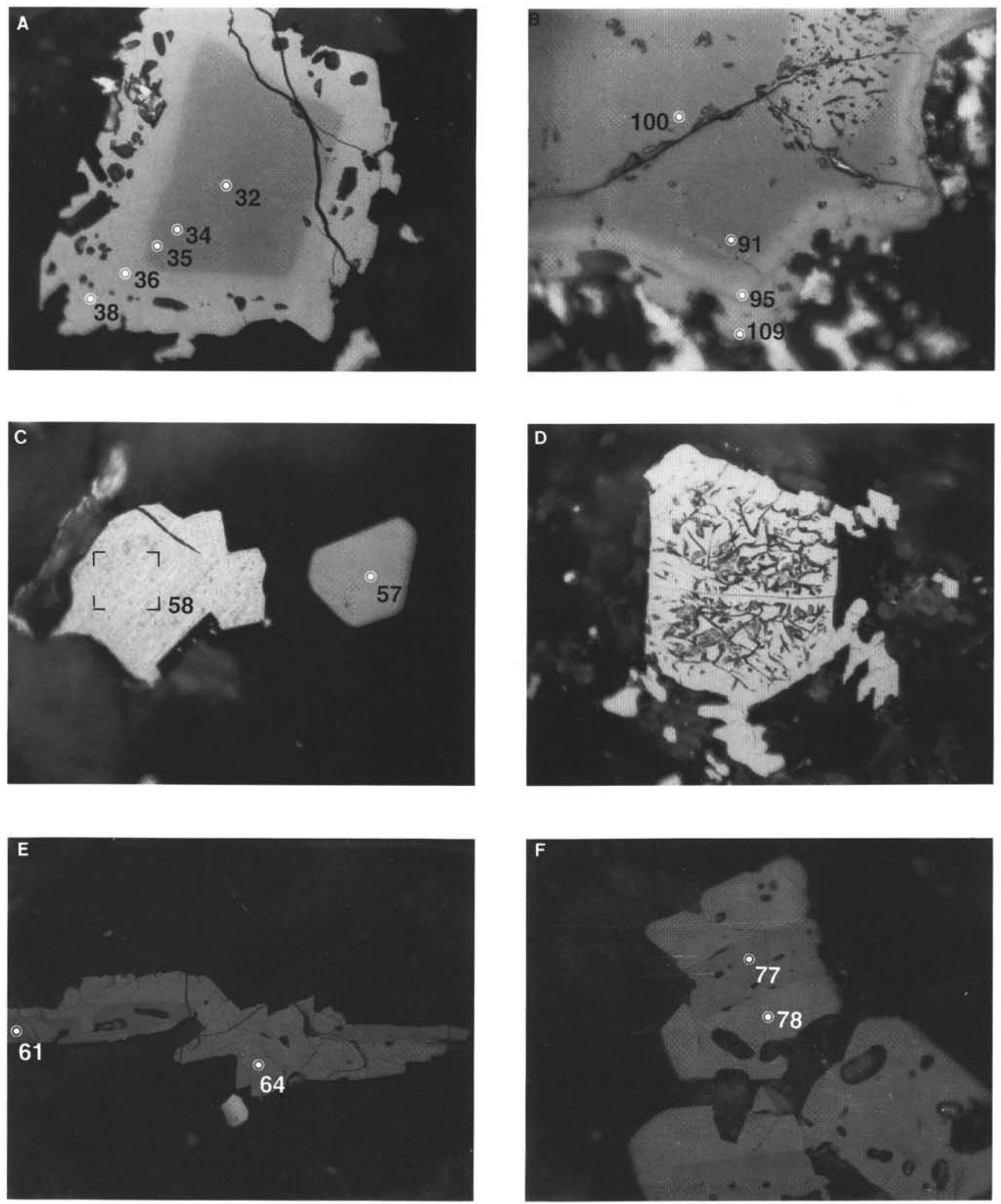

Plate 1. Representative magmatic and oxidation textures in samples from Leg 144. A. Chrome spinel with mantling titanomagnetite (Sample 144-874B$24 \mathrm{R}-1,51-53 \mathrm{~cm}$ ). B. Xenocrystic chrome spinel with mantling titanomagnetite (Sample 144-871C-38R-2, 104-106 cm). C. Homogeneous and highly altered (C5) titanomagnetite grains (Sample 144-878A-89R-3, 75-77 cm). D. Large skeletal titanomagnetite exhibiting extensive development of shrinkage cracks from low-temperature alteration (Sample 144-873A-18R-1, 10-12 cm). E. Composite intergrowth of titanomagnetite and ilmenite of probable magmatic origin (Sample 144-874B-24R-4, 42-44 cm). F. Composite titanomagnetite-ilmenite intergrowth (Sample 144-878A-91R-3, 86-88 cm). Numbers and white (black) dots indicate location of microprobe analyses (see Tables 2-5). All photomicrographs are taken in oil immersion with uncrossed nicols. The widths of the field of view for Plates IA-1D and 1E-1F are 300 and $150 \mu \mathrm{m}$, respectively. 

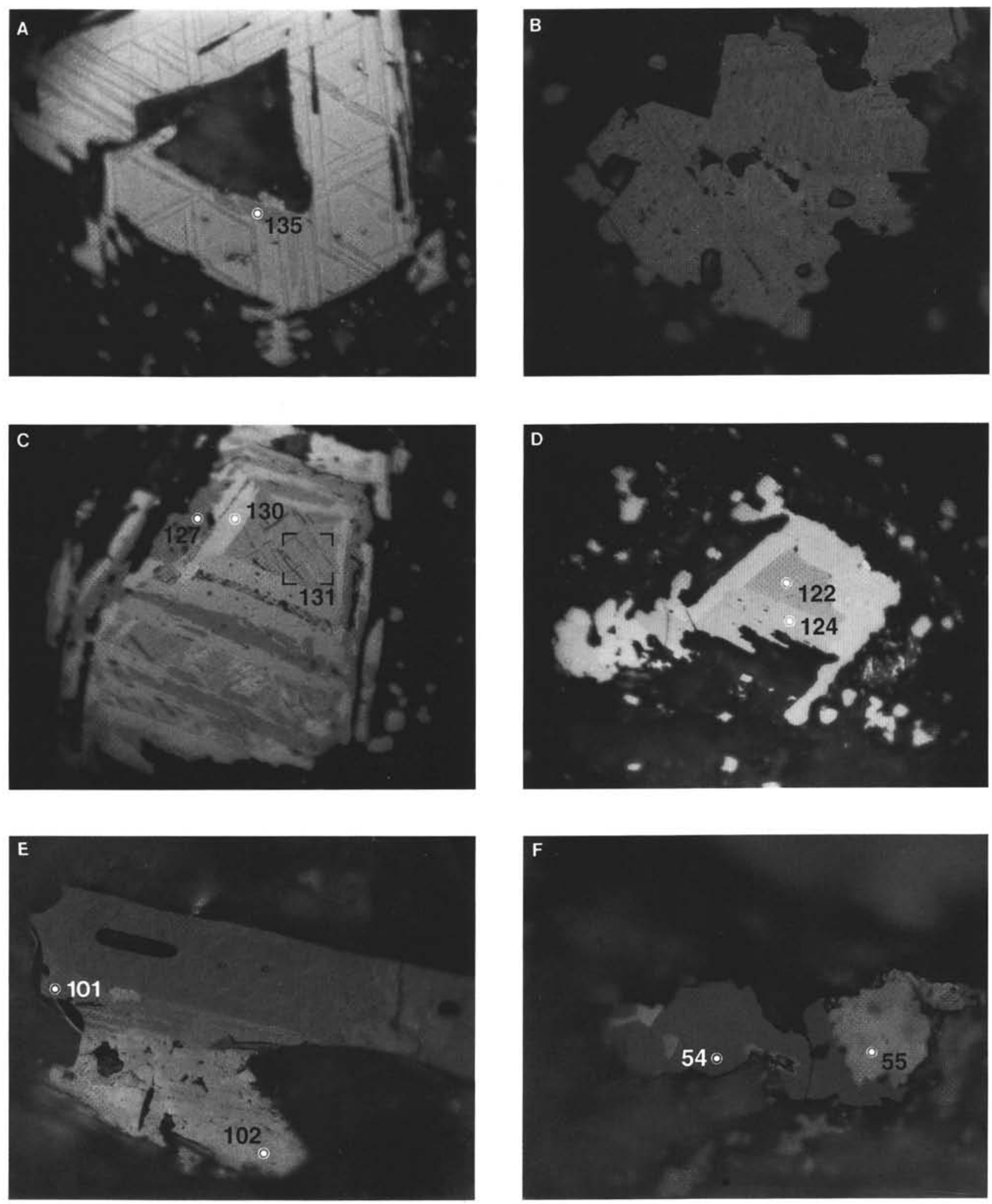

Plate 2. Representative alteration textures in samples from Leg 144. A. Titanomagnetite grain with oxyexsolved ilmenite lamellae that are slightly mottled (incipient C4 alteration) (Sample 144-873A-17R-1, 50-52 cm). B. Typical Stage C5 altered titanomagnetite illustrating the near-complete replacement of the titanomagnetite by rutile + titanohematite (Sample 144-878A-89A-4, 25-27 cm). C. Highly oxidized (C7) grain illustrating the development of pseudobrookite and titanohematite with relict Al-rich titanomagnetite; note the exsolved spinel lamellae (black) within the titanomagnetite host (Sample 144-873A-17R-1, 36-38 $\mathrm{cm}$ ). D. Highly oxidized (C7?) titanomagnetite grain with coarse titanohematite lamellae surrounding a relict Al-rich titanomagnetite (Sample 144-873A-17R-1, $36-38 \mathrm{~cm}$ ). E. Altered ilmenite grain illustrating the development of fine ferrirutile lamellae (fine lamellae oblique to grain boundary) and titanohematite alteration along the grain margin; the whiter grain in the lower part of the photo is, in part, a Ti-poor titanohematite (Sample 144-872B-5R-3,11-13 cm). F. Magnesioferrite (black) intergrown with Ti-poor titanohematite (white) (Sample 144-876A-16R-1, 78-80 cm). Numbers and white (black) dots indicate location of microprobe analyses (see Tables 2-5). All photomicrographs are taken in oil immersion with uncrossed nicols. The widths of the field of view for Plates $2 \mathrm{~A}-2 \mathrm{D}$ and $2 \mathrm{E}-2 \mathrm{~F}$ are 300 and $150 \mu \mathrm{m}$, respectively. 